\title{
28 Research Square \\ Engine Behaviour Characterisation of Roselle Biodiesel Through Experimental and Empirical Method
}

\section{Tikendra Nath Verma}

Maulana Azad National Institute of Technology Bhopal

Upendra Rajak

RGM College of Engineering and Technology

\section{Satishchandra Salam}

National Institute of Technology Manipur

Asif Afzal ( $\square$ asif.afzal86@gmail.com )

P. A. College of Engineering (Affiliated to Visvesvaraya Technological University

\section{A. Muthu Manokar}

B. S. Abdur Rahman Crescent Institute of Science and Technology

Abdul Aabid

Prince Sultan University

Muneer Baig

Prince Sultan University

\section{Research Article}

Keywords: Roselle biodiesel, Injection timing, ANN, Performance, Emission, Combustion

Posted Date: June 1st, 2021

DOl: https://doi.org/10.21203/rs.3.rs-530247/v1

License: (c) (1) This work is licensed under a Creative Commons Attribution 4.0 International License. Read Full License 


\section{Abstract}

Persistent increase in demand and depletion of world fossil fuel reserve has necessitated the lookout for alternative fuels. One such indigenous biodiesel with significant potential is the biodiesel extracted from Roselle whose technical feasibility to operate with compression ignition engine is investigated in this study. Experimental and empirical methodologies had been employed to characterise the fuel blends while operating at engine loads of $25 \%, 50 \%, 75 \%$ and $100 \%$, and with fuel injection timings of $19^{\circ}, 21^{\circ}$, $23^{\circ}, 25^{\circ}$ and $27^{\circ}$ bTDC. Results showed that for $20 \%$ blend, with advanced injection timing from $19^{\circ}$ bTDC to $27^{\circ}$ bTDC at full load, brake specific fuel consumption and exhaust gas temperature for $20 \%$ blend was higher by $15.84 \%$ and $4.60 \%$, while decrease in brake thermal efficiency by $4.4 \%$. Also, $18.89 \%$ reduction in smoke, $5.26 \%$ increase in $\mathrm{CO}_{2}$ and $12.94 \%$ increase in NOx were observed. In addition, an empirical model was developed for full range characterisation. The artificial neural network model thus developed to characterise all the 10 variables was able to predict satisfactorily with r-squared value of $0.9980 \pm 0.0011$. Further, high correlation amongst certain variables indicated to plausible empirically reduced models.

\section{Introduction}

The limited reserve and severe environmental issues related with the utilization of non-renewable energy sources necessitate researches on alternative fuels. Various researchers have shown that the esters derived from certain non-edible oils could serve as a substitute fuel [1, 2]. Also it has been shown that lower biodiesel blends exhibit very similar behaviour with standard diesel fuel. Generally, as compared with diesel fuel, neat biodiesel fuel and its blends have higher density, higher kinematic viscosity, lower calorific value and lower volatility [3, 4]. In consequence, these different critical physico-chemical properties could yield different engine characteristics. Difference in fundamental operational properties such as atomization of fuel, ignition delay and rate of fuel mass burn etc. could directly result to different performance, combustion and emission behaviour.

In the operation of internal combustion engine (ICE), a highly influencing parameter is the fuel injection conditions. During the cyclic operation, a pre-metered amount of charge is to be injected at the end of compression stroke [5]. The timing at which the fuel is injected into the combustion chamber is referred as the fuel injection timing (FIT), and is measured as crank angle before top dead centre (bTDC). And, the associated pressure at which the charge is injected is referred as fuel injection pressure (FIP). Advanced injection of charge would facilitate more burning of charge before piston reaches TDC and consequently, maximum cylinder pressure would also be observed at advanced FIT [6, 7]. Too much advancement of injection timing may result in inefficiency as sufficient temperature may not be available at the start of combustion. It has also been noticed that retardation in fuel injection timing could reduce NOx emission without any significant impact on the engine performance $[8,9]$. Given the fundamental role of fuel injection conditions in the behaviour of this heat engine, the following section discusses what recent researches have reported on how FIT influences on ICE performance, combustion and emission characteristics [10]. 


\section{Effects of FIT}

In the controlled combustion of fuel inside the combustion chamber, thermodynamic variables such as temperature and pressure directly dictate the process. Such variables heavily influences the combustion process even upto very small length and time scales. Following the fuel injection, sufficiently high enough velocity is required to facilitate proper atomisation and mass dispersion throughout the combustion chamber. Therefore, in addition to the pressure at which fuel is injected, the timing of fuel injection largely determines the evolution of the combustion process. Thus, in addition to a large variety of variables, advancement or retardation of the fuel injection timing as the piston head reaches TDC for the subsequent power stroke determines the evolution of combustion.

To report a few recent investigations on the effects of only FIT on engine behaviour, Suryawanshi and Deshpande [11] studied the effect of decreased FIT by $4^{\circ} \mathrm{CA}$ on the performance and emission of a Karanja oil methyl ester fueled in $\mathrm{Cl}$ engine. The addition of biodiesel in the fuel blend caused a significant reduction in smoke, hydrocarbon and carbon monoxide emission but there was a small increase in NOx emission with standard FIT. Similarly, Nwafor [12] studied the effect of increasing FIT by $3.5^{\circ} \mathrm{CA}$ bTDC on the engine exhaust fueled with natural gas as a primary fuel in dual-fuel $\mathrm{Cl}$ engine emission and performance. The experiment test engine had original FIT of $30^{\circ} \mathrm{CA}$ bTDC. The results showed that increased FIT reduced $\mathrm{BTE}, \mathrm{CO}_{2}$ and $\mathrm{CO}$. Various authors also reported that retarding the FIT reduced NOx emission $[13,14,15]$. On the contrary, Rahman et al. [16] reported increase in HC, CO and smoke emission increases while NOx emission decreases with retardation in FIT. These type of fuel and operating condition specific observations were also reported by many authors where BSFC and EGT increased while BTE decreased with advanced FIT [17].

To extend these engine characterisation with operating conditions defined by more than FIT, the following investigations studied the combined effect of fuel injection conditions with CR. Along with increase/decrease in FIT, Raheman and Ghadge [18] observed that BSFC decreases while BTE ad EGT increases with increase in CR from 18 to 20 . Laguitton et al. $[19,20]$ also examined the effects of FIT and $\mathrm{CR}$ for different biodiesels. The study reported that there were no major deviation in the performance and combustion behaviour, but a small reduction in $\mathrm{NOx}$ and $\mathrm{CO}_{2}$ emission and increase in smoke emission were observed with retarding FIT and decreasing CR. Such observations were also reported by Sayin and Gumus [21] where the effect of CR, FIT and FIP on emission and performance with biodiesels were studied. A comprehensive observation from the study was that engine performance and NOx increased with increase in CR, FIP and FIT. Such observations of the combined effect of CR and fuel injection conditions were also reported in few other studies [22].

On extended studies involving optimisation of engine operation, some authors have reported that the optimal FIT for different biodiesel depended on engine inputs of engine torque, engine speed and fuel injection duration $[23,24,25]$ thus consolidating the role of fuel injection conditions in the ICE operation. Possibly, reduction in FIT could greatly influence on the combustion duration and therefore could change combustion duration which could lead to either a successful combustion or incomplete combustion [26, 
27]. On another account involving ignition delay (ID) along with fuel injection conditions, Bari et al. [28] reported that ID was higher with advanced FIT. It was speculated that proper mixing of air-fuel mixture was promoted inside the combustion chamber with advanced FIT, and thus facilitating better fuel combustion in the premixed combustion zone.

As demonstrated by these few reported studies, what is clearly evidenced is that the characterisation of engine behavior posits as a challenge when all the operating conditions are to be accounted for. The thermochemical interactions entirely changes when the physico chemical properties of the fuel changes. Therefore, it is a necessity to investigate on how different fuel with different properties behave under specific operating conditions. In this regard, we investigated how the indigenous biodiesel from Roselle oil behaved under operating conditions largely defined by critical parameters of fuel injection conditions.

\section{Artificial neural network}

In the paradigm of learning in human movement studies, the activation or inhibition across large networks of neurons are primarily attributed for how human are able to learn various movements. Such networks have a very unique feature to develop and learn features from previous movements and generalise them to new situations. To study how these networks of neurons are able to conform to patterns of the inputs [29] networks of artificial neurons were designed. Popularly known as artificial neural networks (ANNs), they have find substantial application for classification and prediction across various domains [30] in artificial intelligence and machine learning. As a supervised machine learning algorithm, it maps the input to the target values through iterative weights and biases adjustment and hence usually performs satisfactorily when large enough dataset is available. During the training, the adjustment of coefficient allows the network to develop plausible empirical patterns of the dataset. But such patterns cannot explain the mechanistic relationship between the involved parameters, and hence they are treated as 'black-box' models. As such the drawback might be, in the research of alternative fuels operating with internal combustion engines (ICE), the lack of unified analytical relationships has only substantiated why alternative approach to modelling ICE are required. It is evidenced by how the following previous researches have employed ANN to achieve the prediction of various variables of interest involved in ICE research.

To report a few, Alonso at al. [31] used ANN to develop models for the ICE operation with diesel for the optimisation of performance and emission using genetic algorithm. The ANN model had inputs of engine operating speed, mass of air and injected fuel, fuel injection conditions, and temperature of water and intake. It predicted emission parameters of $\mathrm{NO}, \mathrm{PM}, \mathrm{CO}, \mathrm{HC}$ and BSFC. A more computationally intensive study was performed for ICE operation with blends of WCO by Ghobadian et al. [32], where various ANN were evaluated for best prediction accuracy. Using speed and blending, the network predicted brake power, BSFC, torque, $\mathrm{HC}$ and $\mathrm{CO}$ emissions. Similar studies were also reported by Togun and Baysec [33]. They also used ANN to develop torque and BSFC from operating parameters of spark advance, throttle position and engine speed. Similar study for blends with WCO biodiesel was conducted by Pai and Rao [34] where load, blend, CR and FIT were used to predict BTE, EGT, BSEC, smoke, NOx and UHC. In addition 
to ANN model using brake power and blending to predict BTE, BSFC, CO, smoke, NOx and HC, Sharon et al. [35] presented a SIMULINK representation of the model.

Statistical flair to the paradigm was added by Roy et al. [36] where various statistical parameters were incorporated to evaluate the network's prediction accuracy. The study predicted $\mathrm{BTE}, \mathrm{BSFC}, \mathrm{NOx}, \mathrm{CO}_{2}, \mathrm{PM}$ from load, EGR, fuel injection pressure, and injected fuel mass. In addition with a more empirical perspective, [37] coupled ANN model with limited solutions derived from detailed numerical solutions to highlight that large computational resources can be saved thus. Predicting 17 variables of performance, combustion and emission, the study also reported empirical redundancy thus indicating to plausible reduced empirical models of ICE operation. As evidenced from these few studies, ANN have been popularly employed to build empirical models of ICE operation. It has helped predict approximated engine behaviour which is necessary for a variety of industry applications including quick diagnostics and fault detection. However, what is also evident is that these reported studies did not studied the empirical structure of the system. Therefore, in this study, we also proposed to evaluate the empirical redundancy in the dataset to investigate on plausible empirically reduced models of the system.

Now to conclude, the objective of this study was to explore the technical feasibility of using Roselle biodiesel and its blend as an operating fuel in $\mathrm{Cl}$ engine. The biodiesel was derived form Roselle seeds by using transesterification technique. Experimental test were performed under different engine loading of $25 \%, 50 \%, 75 \%$ and $100 \%$ with blend ratios of $0 \%, 20 \%, 40 \%, 60 \%, 80 \%$ and $100 \%$ and at different FITs of $19^{\circ}, 21^{\circ}, 23^{\circ}, 25^{\circ}$ and $27^{\circ} \mathrm{bTDC}$. The engine behaviour in terms of performance, combustion and emission parameters were studied experimentally. This experimental data was further used to build an empirical model using ANN. After analysing the empirical dependencies of the engine responses, plausible empirically reduced models were also studied.

\section{Experimental Procedure}

\section{Fuel preparation}

One litre of crude Roselle oil was taken in a repository and heated to a temperature around $65-70{ }^{\circ} \mathrm{C}$ at low stirring speed. In a separate flask, a fixed quantity of alcohol (methanol) and sodium hydroxide $(\mathrm{NaOH})$ as a catalyst were strenuously shaken and poured into a container, and was closed with an airtight lid. The sample was mixed for an hour at minimum speed by the use of magnetic stirrer and then it was transferred into a separation funnel to allow to settle overnight at room temperature [38, 39, 54]. The Roselle oil is turned into the biodiesel form and glycerol is separated through the funnel. The biodiesel floated at the top and the glycerol stayed at the bottom. The separated crude biodiesel phase was then washed out with warm deionised water until the washed water becomes clear. The evaporation process then removed the remaining water under atmospheric condition.

Table 1 shows the requirement for the production of Roselle biodiesel through transesterification technique. The total amount of biodiesel yield produced from Roselle oil using $\mathrm{NaOH}$ catalyst is $83 \%$. The 
fatty acid composition was determined under the optimal condition by using a gas chromatographymass spectrometry. Table 2 shows the composition of fatty acid composition of Roselle oil. The important properties of fuel blend and diesel have been determined as per the ASTM standards in the analytical laboratory. The important properties of different tested fuels are shown in Table 3.

\section{Experimental procedure}

All experimental tests were performed at Internal Combustion Engine Laboratory of Department of Mechanical Engineering, National Institute of Technology Manipur, India at a single-cylinder 4-stroke $\mathrm{Cl}$ engine whose technical specifications are shown in Table 4. The test were conducted for Roselle biodiesel and its blends of LA20, LA40, LA60, LA80 and LA100 with FITs of $19^{\circ}, 21^{\circ}, 23^{\circ}, 25^{\circ}$ and $27^{\circ}$ bTDC, engine loadings of $25 \%, 50 \%, 75 \%$ and $100 \%$ with a fixed CR of $17.5: 1$ and constant engine speed of $1500 \mathrm{rpm}$. The schematic diagram of the experimental test setup is illustrated in Fig.1. Roselle plant and seeds is shown in Fig.2. A dynamometer was used to apply load to the test engine. Initially, engine was started with diesel fuel and the engine is allowed to warm-up for about 15-20 minutes to attain steady state condition. Testo-350 gas analyser was used for measuring the exhaust emissions. Carbon dioxide $\left(\mathrm{CO}_{2}\right)$, oxides of nitrogen ( $\mathrm{NOx}$ ), and smoke emission were measured from the exhaust gas by using the analyser probe. The test matrix and acronyms used in the present research work for diesel, Roselle and its blend is shown in Table 5.

\section{Uncertainty analysis}

In general, all trial estimation is subjected to errors and uncertainties. The uncertainty in the investigation results could cumulate from selection of sensor, operating conditions, calibration of setup, test procedure and observation. Summary of the apparatus used in the investigation including the estimation range and precision of the instruments are given in Table 6. Uncertainty analysis for the experimental setup was required to reduce the error as well as verify the experimental accuracy. To perform the uncertainty analysis, following method is discussed by $[40,41,42,55]$. The overall uncertainty analysis of the experimental was found out by using the following equation:

Overall uncertainty $(\%)=$ square root of $\left[(0.2)^{2}+(1.0)^{2}+(0.15)^{2}+(0.5)^{2}+(0.2)^{2}+(1.0)^{2}+(0.15)^{2}+(1.0)^{2}\right.$ $\left.+(1.0)^{2}+(1.0)^{2}+(0.5)^{2}\right]$

Total percentage of uncertainty $= \pm 2.3 \%$.

\section{ANN model}

As discussed in introduction, empirical approximations of ICE operation are also required for the ICE research. Since there are limitations for the characterisation of entire operation range through experimental methods, we employed ANN to develop empirical model for possible use in prediction or optimisation problem for the ICE operation with Roselle biodiesel. 
As summarised in Fig. 3. and Table 7, the employed ANN architecture had 3 input nodes representing loading, blending and FIT. It had 10 output nodes to predict the associated performance variables of BTE, BSFC and EGT, combustion variables of MRPR and ID, and emission variables of $\mathrm{CO}_{2}$, $\mathrm{NOx}$ and smoke. The response of cylinder pressure and heat release rate was not included in the empirical analysis because of the different data structure. These two variables were operating at $100 \%$ loading condition only. The architecture had only one hidden layer which maps non-linear relationships from the input to the targets. And based on some thumb rules available on the literature [43,44], the network was trained with 6 nodes in the hidden layer. Furthermore, having found satisfactory prediction results with the chosen architecture, no other architecture was checked for better performance and subsequent analysis was preceded with the 3-6-10 architecture. This also connoted to the suggestion of empirically reduced model as will be discussed later. In addition, Levenberg-Marquadt backpropagation algorithm was employed as it is popularly reported to converge faster with minimum mean square error [45]. This was achieved with the function 'trainlm' from the Neural Network Toolbox available in MATLAB 2016a.

The experiments with different operating conditions of 4 loading conditions, 6 blending percentages and 5 FITs yielded to $120(4 * 5 * 6)$ operating conditions. Out of these, $70 \%$ corresponding to 84 conditions were randomly selected to train the network during which iterative adjustments were made to the weights and biases of the network. Validation of the network generalisation was achieved with another $15 \%$ corresponding to 18 conditions. This same data subset was used for terminating the training when the network generalisation didn't improve. At the end of training, remaining 15\% corresponding to 18 conditions which were not involved at all in the training were used to evaluate the performance of network. These random divisions of data into these three sets were conducted using the 'dividerand' function available in MATLAB 2016a. In addition, prior to the training, the dataset was normalised as shown in Equation (1):

$X n=(X i-X \min ) /(X \max -X \min )(1)$

where $\mathrm{Xn}$ is normalised value of $\mathrm{Xi}$; $\mathrm{Xmin}$ and $\mathrm{Xmax}$ are respectively minimum and maximum of the corresponding variable.

But a range of $(0.05-0.95)$ was used instead of $(0,1)$ to avoid possible arithmetic operations such as dividing by zero to it as it will be returned as 'not a number' ( $\mathrm{NaN})$ by the computational environment. In addition, it could help achieve faster training as transformations of extremely small values are avoided [46]. And with this, the network can avoid computing activation functions of extreme values without compromising the empirical accuracy. This was achieved with the modification of equation (1) into as equation (2):

$X n=(b-a) \cdot(X i-X \min ) /(X \max -X \min )+a(2)$

where $a$ and $b$ are limits of the normalised value correspondingly substituted by 0.05 and 0.95 .

And rearranging equation (2) to get the original value: 
$X i=X \min +(X \max -X \min ) \cdot(X n-a) /(b-a)(3)$

For the presentation of results, the empirical model thus achieved was used to calculate the expected engine output under different operating conditions within the range of experiment. Each range of input variable was subdivided into additional 20 points to simulate the full range engine behaviour. These replicated data points were used to analyse the empirical perspective of the study.

\section{Results And Discussion}

\section{Brake thermal efficiency}

It is defined as how efficiently the engine converted the chemical energy of the combustible fuel into useful work. The variation in BTE with different injection timing and engine load for various tested fuel is depicted in Fig. 4 (a-e). Based on the experimental result, it was found that BTE decreased with increase in FIT from $19^{\circ}$ to $27^{\circ}$ bTDC. At higher load condition, BTE was higher for LA20 blend with retarding in FIT, and it reduced with advancement in FIT compared to other biodiesel blends as similarly reported by panneerselvam et al. [47]. Retarding the FIT could cause the early start of fuel combustion and continue till the end of power stroke. It was noticed that BTE was higher with retarded FIT of $19^{\circ}$ bTDC with $15.65 \%$ at low load to $33.95 \%$ for diesel fuel at higher load, and for LA20,15.1\% at lower load to $33 \%$ at higher load. While it decreased with advanced FIT of $27^{\circ}$ bTDC with $13.7 \%$ at lower load to $32.2 \%$ fuel for diesel fuel at higher load, and for LA20, 13.2\% at lower load to 31.8\% at higher load condition. The BTE for LA20 and LA40 were recorded nearly close to diesel fuel while on the other hand, LA60, LA80 and LA100 were lower compared to diesel fuel.

\section{Brake specific fuel consumption}

Brake specific fuel consumption is a measure of charge efficiency in the engine and hence it is an important parameter to analyse how effectively an engine fuel is converted into work done. The variation in BSFC with different FIT and load for different tested fuel is shown in Fig. 5 (a-e). BSFC increased with increase in FIT from $19^{\circ}$ to $27^{\circ}$ bTDC. At higher load, the BSFC was $0.268 \mathrm{~kg} / \mathrm{kWh}$ for diesel fuel and $0.318 \mathrm{~kg} / \mathrm{kWh}$ for LA100 at standard FIT (23 $\mathrm{bTDC}$ ). The Roselle biodiesel as a fuel, for pure Roselle biodiesel as fuel (LA100) the BSFC increased to $0.331 \mathrm{~kg} / \mathrm{kWh}$ and $0.352 \mathrm{~kg} / \mathrm{kWh}$ with advanced FIT of $25^{\circ}$ and $27^{\circ} \mathrm{bTDC}$, and it decreased to $0.302 \mathrm{~kg} / \mathrm{kWh}$ and $0.276 \mathrm{~kg} / \mathrm{kWh}$ with retarded FIT with $21^{\circ}$ and $19^{\circ}$ bTDC compared to standard FIT. One possible reason for this increment in BSFC with advanced FIT could be due to longer ignition delay duration, and therefore more fuel getting accumulated in the process with increase in fuel consumption rate. Also, with increase in advancement of FIT from $19^{\circ}$ to $27^{\circ} \mathrm{bTDC}$, additional time was accessible for the combustion and therefore that could prompt to better ignition of fuel. It was found that diesel fuel indicated lower BSFC for all FIT compared with Roselle and its blends.

This could be because of lower heating value and higher density of Roselle biodiesel and its blends which lead to more fuel consumption to deliver similar power output with diesel fuel. Therefore, BSFC was found to be lowest with retarded FIT of $19^{\circ}$ bTDC and maximum with advanced FIT of $27^{\circ}$ bTDC for all tested fuels. 


\section{Exhaust gas temperature}

The exhaust gas temperature provides about the quality of combustion. Fig. 6 (a-e) shows the variation of EGT with load at different FIT. EGT increased with advancement of FIT from $19^{\circ}$ to $27^{\circ} \mathrm{bTDC}$. This could be due to advanced FIT resulting in higher ignition delay period thus leading to increased cylinder temperature and pressure. At full load condition, EGT was recorded as $350.8^{\circ} \mathrm{C}$ and $338.1^{\circ} \mathrm{C}$ for diesel and LA 100 at $19^{\circ}$ bTDC. At $21^{\circ}$ bTDC, $23^{\circ}$ bTDC, $25^{\circ}$ bTDC and $27^{\circ}$ bTDC it was $357.8^{\circ} \mathrm{C}, 365.8^{\circ} \mathrm{C}$, $372.4^{\circ} \mathrm{C}$ and $379.5^{\circ} \mathrm{C}$ for diesel and $340.1^{\circ} \mathrm{C}, 343.2^{\circ} \mathrm{C}, 346.8^{\circ} \mathrm{C}$ and $349.7^{\circ} \mathrm{C}$ for LA 100 respectively. Therefore, the experimental result showed that retardation in FIT reduced the EGT by $3-6^{\circ} \mathrm{C}$ whereas it increased for all tested fuels at advanced FIT.

\section{Combustion characteristics}

\section{Cylinder pressure}

The cylinder pressure is necessary to study the behaviour of combustion in the combustion chamber and also for examination of engine performance. The variation in cylinder pressure with crank angle at full load at different FIT is shown in Fig. 7 (a-e). It was found that cylinder pressure increased with increase in FIT. Diesel fuel indicated higher cylinder pressure for all engines operating condition at different FIT compared to other biodiesel and its blends. At $19^{\circ}$ bTDC, the cylinder pressure was recorded to as 98 , 96.5, 95.7, 94.5, 93.9 and 93.3 bar for diesel, LA20, LA40, LA60, LA80 and LA100. Similarly, at $21^{\circ}, 23^{\circ}$, $25^{\circ}$ and $27^{\circ}$ bTDC cylinder pressure were measured as $101,104,106.8$ and 108 bar for diesel and 97.1, $101,102.2$ and 103.2 bar for pure LA100. This clearly indicated that cylinder peak pressure was lower for biodiesel and its blends compared to diesel fuel. This could be mainly due to lower ignition delay period. The cylinder peak pressure decreased with retarded FIT to $19^{\circ}$ bTDC and increased with advanced FIT. The maximum cylinder peak pressure recorded at $19^{\circ}$ bTDC was less than that of $23^{\circ}$ bTDC by 5 bars for diesel fuel. Similar difference of 5-7 bar was observed for LA20, LA40 and LA60, LA80 and LA100. Further, it increased with FIT by approximately 4 bars for diesel, 3-4 bars for LA20, LA40 and LA60, LA80 and LA100. Thefore, the mixing of air-fuel was better with advanced FIT and therefore its results in better combustion process of the fuel. This also leaded to increase in the cylinder pressure because of longer ignition delay.

\section{Heat release rate}

It is defined as the amount of heat generated by the combustion mixture at a specified crank angle (instantaneous heat release rate). The comparison of HRR with crank angle at full load condition at different FIT is illustrated in Fig. 8 (a-e). It was noticed from the experimental results that retardation in FIT reduced the HRR for all testing fuel. The peak HRR for LA20 and LA100 was 66.3 and $54.8 \mathrm{~J} /{ }^{\circ} \mathrm{CA}$ at $19^{\circ} \mathrm{bTDC}, 67.2$ and $59.8 \mathrm{~J} /{ }^{\circ} \mathrm{CA}$ at $21^{\circ} \mathrm{bTDC}, 66.4$ and $58.2 \mathrm{~J} /{ }^{\circ} \mathrm{CA}$ at $23^{\circ} \mathrm{bTDC}, 68.5$ and $58.6 \mathrm{~J} /{ }^{\circ} \mathrm{CA}$ at $25^{\circ} \mathrm{bTDC}$ and 68.9 and $63.1 \mathrm{~J} /{ }^{\circ} \mathrm{CA}$ at $27^{\circ} \mathrm{bTDC}$ respectively. This could be due to decrease in biodiesel content in the fuel mixture resulting in increase in premixed combustion HRR for all FIT. This may be due to the higher viscosity and density of biodiesel fuel which also lead to poor mixing and atomization of 
fuel. At $19^{\circ} \mathrm{bTDC}$, the peak HRR of diesel fuel was $67.2 \mathrm{~J} /{ }^{\circ} \mathrm{CA}$, whereas for $21^{\circ} \mathrm{bTDC}, 23^{\circ} \mathrm{bTDC}, 25^{\circ}$ bTDC and $27^{\circ}$ bTDC it was $67.9,68.5,70.2$ and $73.2 \mathrm{~J} /{ }^{\circ} \mathrm{CA}$ respectively. Therefore it may be concluded that retardation in FIT reduced the ignition delay period which resulted to lower peak HRR and lower premixed combustion.

\section{Ignition delay}

The ignition delay is the time duration measured in degree crank angle between the start of injection of fuel to the point where the combustion starts. The variation of ignition delay with different engine loads and FITs is depicted in Fig.9 (a-e). It was observed from the figure that ignition delay reduced with increase in engine load and with advanced FIT. The increase in advanced FIT resulted in increase in ignition delay period, and therefore more fuel is collected inside engine cylinder thus leading to increase in premixed combustion $[52,53]$. This resulted in higher temperature and pressure. This was responsible for the observation of ignition delay period being higher for diesel fuel than with Roselle biodiesel and its blends at all operating FIT. At full load, ignition delay was lowered to $9.05^{\circ}, 10.38^{\circ}, 11.76^{\circ}, 13.23^{\circ}$ and $14.73^{\circ}$ for LA100 compared to that of $10.12^{\circ}, 11.75^{\circ}, 13.1^{\circ}, 14.6^{\circ}$ and $16.25^{\circ}$ for diesel fuel at $19^{\circ}, 21^{\circ}$, $23^{\circ}, 25^{\circ}$ and $27^{\circ}$ bTDC respectively.

\section{Maximum rate of pressure rise}

The variation in MRPR with load at different FIT is illustrated in Fig. 10 (a-e). It was observed that MRPR increased with increase in load and FIT for all tested fuels. Among all the tested fuels, diesel fuel indicated higher pressure rise compared to other tested fuels in all engine operating conditions. The reason for this increase in pressure rise could be due to more fuel injected with advanced FIT, thus taking more time to charge the fuel-air mixture and creating a maximum pressure when piston reached to TDC. At full load the MRPR was 4.7, 5.3, 5.8, 5.62 and 5.7 bar $/{ }^{\circ} \mathrm{CA}$ for LA100 which is lower as compared to diesel fuel by about $5.55,5.85,5.98,6.25$ and 6.37 bar $/{ }^{\circ} \mathrm{CA}$ at $19^{\circ}, 21^{\circ}, 23^{\circ}, 25^{\circ}$ and $27^{\circ}$ bTDC respectively.

\section{Emission characteristics}

\section{Smoke emission}

The variation in smoke emission with different engine load and FIT is shown in Fig. 11 (a-e). It was noticed that smoke emission increased with increase in engine load and decreased with advanced FIT. Smoke emission was maximum for diesel fuel than with Roselle biodiesel and its blends at all FITs. For example, as presented in figure increased FIT, the smoke emission decreased by $12.90 \%, 13.81 \%, 14.23 \%$, $14.78 \%$ and $15.03 \%$ for LA20, LA40, LA60, LA80 and LA100 at full load condition respectively. It could be due to the presence of more oxygen content in the biodiesel, therefore the fuel rich zone decreased and also restricted the formation of smoke emission $[48,49]$. Smoke emission indicated the incomplete combustion of charge in a fuel rich zone. Smoke emission were found to be about 1.82, 1.72, 1.64, 1.57 
and 1.53 BSN for diesel fuel compared to that of $1.57,1.55,1.44,1.39$ and $1.37 \mathrm{BSN}$ for LA100 at $19^{\circ}$, $21^{\circ}, 23^{\circ}, 25^{\circ}$ and $27^{\circ}$ bTDC at full load condition respectively.

\section{$\mathrm{CO}_{2}$ emission}

The variation of $\mathrm{CO}_{2}$ emission with load at different FIT is illustrated in Fig.12 (a-e). The $\mathrm{CO}_{2}$ emission increased with increased in FIT and decreased with increase in engine load for all tested fuels. The $\mathrm{CO}_{2}$ emission was recorded lower for diesel fuel with retarded FIT. At higher engine load, $\mathrm{CO}_{2}$ emission was higher for LA100 and were 823.2, 833.84, 845.6, 905.1 and $943.2 \mathrm{~g} / \mathrm{kWh}$ compared to that of diesel fuel by $779.4,798.2,807.23,816.2$ and $824.23 \mathrm{~g} / \mathrm{kWh}$ at $19^{\circ}, 21^{\circ}, 23^{\circ}, 25^{\circ}$ and $27^{\circ} \mathrm{bTDC}$ respectively. This may be due to increase in ignition delay and thereby facilitating proper mixing of air-fuel mixture. This could provide fuel rich zone and lead to better combustion of fuel and consequently increase in $\mathrm{CO}_{2}$ emission.

\section{NOx emission}

The variation in NOx emission with load at different FIT as shown in Fig.13 (a-e). As shown in the figure increased FIT from $19^{\circ}$ to $27^{\circ}$ bTDC resulted in increased NOx emission for all tested fuels. Diesel fuel emitted higher NOx emission compared to biodiesel and its blends for all FIT as similarly reported by Singh et al. [49]. This could be explained by increase of ignition delay with increased in FIT thereby lowering gas temperature at early fuel injection. Because of the longer ignition delay, it would increase the fuel quantity that burn in the premixed combustion phase, thus resulting in a higher cylinder gas pressure and higher temperature, and finally increased NOx emission [50]. At $19^{\circ}$ bTDC, higher NOx emission of $255.58 \mathrm{ppm}$ was observed for LA20 at low load, and $2835.8 \mathrm{ppm}$ at full load. Similarly at $21^{\circ} \mathrm{bTDC}, 23^{\circ}$ bTDC, $25^{\circ}$ bTDC and $27^{\circ}$ bTDC, it was $267.4,299.36,326.7$, and 338.2 ppm at low load whereas 3050.1 , $3165.5,3254.2$ and $3257.7 \mathrm{ppm}$ at full load condition respectively. All other biodiesel blends produced lower NOx emission than LA20 due to lower calorific value and higher viscosity of diesel fuel.

\section{ANN model performance}

As it was indicated by a significantly high Pearson correlation coefficient (value for representative variable of BTE as $r=0.9996)$, the ANN model could predict with satisfactory accuracy. It is visualised in Fig 14(a) where the slope of the linear polynomial fitted to the scatter data points is very close to 1 (1.001). Here, a slope of unity would meant that the network prediction was exactly the same as the experimental value. Further, the prediction accuracy for all the responses is shown in Fig 14(b) where mean and standard deviation of $r$-value and r-squared-value are presented. For all the 10 responses, $r-$ value and r-squared value were $0.9990 \pm 0.0005$ and $0.9980 \pm 0.0011$ (as mean \pm standard deviation) respectively.

\section{Computational implications}


As it was evident from the engine behaviour reported here, complex non-linear relationship existed among the various output responses with respect to the operating conditions. These complex relationships reinforce the need for alternative approaches for modelling ICE operation. The requirement becomes dire when pragmatic industry feasible solutions are required for developing complete response surfaces. This can be delivered by ANN as empirical compromise that also accounts for the multivariate interactions among the variables of interest at higher dimension. Such complete responses become mandatory for problems like optimisation where it is very important to achieved global solution instead of local solution.

This empirical modelling further lead to plausible empirically reduced models of ICE operation. As shown in Fig 15, despite the non-linearity in the reported responses, significant correlations were observed among the variables of study. As also suggested by [51] collectively representing such correlated responses by a single variable would lessen the associated computational cost of prediction or modelling. For example, the representative variable EGT exhibited very high correlation with other variables of BTE, MRPR and NOx. As seen in Fig 16, such empirical redundancy can be harnessed by using simple linear or quadratic relations to represent those dependencies. Based on the degree of accuracy desired in the prediction of the responses, various numbers of variables with degrees of polynomial can be chosen to be substituted by only one representative response variable.

\section{Conclusion}

The technical feasibility of using Roselle biodiesel as a substitutive fuel for $\mathrm{Cl}$ engine had shown that:

- BTE was higher for diesel fuel compared to biodiesel and its blends for all engine operating conditions, and it increased with retarded FIT.

- NOx emission was lower for biodiesel and its blends than with diesel. Also, NOx emission increased with advanced FIT.

- BSFC for LA100 was higher by $17.3 \%$ at advanced FIT compared to $9.78 \%$ at retarded FIT at full load condition.

- Blend LA20 indicated higher EGT, ignition delay and maximum rate of pressure rise with advanced FIT.

- $\mathrm{CO}_{2}$ emission increased and smoke emission decreased with advanced FIT.

- In addition, an ANN model developed to predict the engine characteristics for further analysis of empirically reduced models indicated that:

- The ANN model was able to predict satisfactorily with an average r-value and r-squared value of $0.9990 \pm 0.0005$ and $0.9980 \pm 0.0011$ (as mean \pm standard deviation) respectively for all 10 responses.

- Empirical redundancy in the dataset can be harnessed by using simple linear or quadratic relations to develop a substitutive variable to represent a set of highly correlated variables. 
- In closure, this study had characterised the engine behaviour of performance, combustion and emission of biodiesel derived from Roselle. In terms of technical feasibility, due to the mixed engine responses with respect to diesel fuel, Roselle can be used as a substitute fuel for diesel fuel. Given the crop's growability and commercial feasibility, Roselle showed a very high potential as an economically viable alternative fuel for $\mathrm{Cl}$ engine.

\section{Declarations}

\section{Acknowledgements}

This research is supported by the Structures and Materials (S\&M) Research Lab of Prince Sultan University

\section{Permissions}

The plant study was done in accordance with relevant guidelines and regulations. And also proper permissions / approval are taken for carrying out this study .

\section{Nomenclature}

\begin{tabular}{llll} 
ANN & Artificial neural network & FIT & Fuel injection timing \\
\hline BO & Diesel fuel $100 \%$ & FIP & Fuel injection pressure \\
\hline BTE & Brake thermal efficiency & ICE & Internal combustion engine \\
\hline BSEC & Brake specific energy consumption & LA20 & Roselle $20 \%+$ Diesel $80 \%$ \\
\hline BSFC & Brake specific fuel consumption & LA40 & Roselle $40 \%+$ Diesel $60 \%$ \\
\hline bTDC & Before top dead centre & LA60 & Roselle $60 \%+$ Diesel $40 \%$ \\
\hline $\mathrm{CO}_{2}$ & Carbon dioxide & LA80 & Roselle $80 \%+$ Diesel $20 \%$ \\
\hline Cl & Compression ignition & LA100 & Roselle biodiesel $100 \%$ \\
\hline CA & Crank angle & MRPR & Maximum rate of pressure rise \\
\hline CO & Carbon monoxide & NOx & Oxide of nitrogen \\
\hline CR & Compression ratio & PM & Particulate matter \\
\hline EGT & Exhaust gas temperature & RPM & Rotation per minute \\
\hline EGR & Exhaust gas recirculation & TDC & Top dead centre \\
\hline HC & Hydrocarbon & UHC & Unburned hydrocarbon
\end{tabular}

\section{References}


1. Forson, F. K., Oduro, E. K., Hammond-Donkoh, E., 2004. Performance of jatropha oil blends in a diesel engine. Renewable Energy. 29, 1135-45. https://doi.org/10.1016/j.renene.2003.11.002.

2. Godiganur, S., Murthy, C. S., Reddy, R. P., 2009. 6BTA 5.9 G2-1 Cummins engine performance and emission tests using methyl ester mahua (Madhuca indica) oil/diesel blends. Renewable Energy. 34, 2172-7. https://doi.org/10.1016/j.renene.2008.12.035.

3. Karabektas, M., 2009. The effects of turbocharger on the performance and exhaust emissions of a diesel engine fuelled with biodiesel. Renewable Energy. 34, 989 - 93. https://doi.org/10.1016/j.renene.2008.08.010.

4. Kinney, A. J., Clemente, T. E, 2005. Modifying soybean oil for enhanced performance in biodiesel blends. Fuel Processing Technology. 86, 1137-47. https://doi.org/10.1016/j.fuproc.2004.11.008.

5. Lin, B. F., Huang, J. H., Huang, D. Y, 2009. Experimental study of the effects of vegetable oil methyl ester on DI diesel engine performance characteristics and pollutant emissions. Fuel. 88, 1779-85. https://doi.org/10.1016/j.fuel.2009.04.006.

6. Lin, C. Y., Lin, H. A., 2006. Diesel engine performance and emission characteristics of biodiesel produced by the peroxidation process. Fuel. 85, 298-305. https://doi.org/10.1016/j.fuel.2005.05.018.

7. Muralidharan, K., Vasudevan, D., 2011. Performance, emission and combustion characteristics of a variable compression ratio engine using methyl esters of waste cooking oil and diesel blends. Applied Energy. 88, 3959-68. https://doi.org/10.1016/j.apenergy.2011.04.014.

8. Muralidharan, K., Vasudevan, D., Sheeba, K. N., 2011. Performance, emission and combustion characteristics of biodiesel fuelled variable compression ratio engine. Energy. 36, 5385-93. https://doi.org/10.1016/j.energy.2011.06.050.

9. Murugan, S., Ramaswamy, M. C., Nagarajan, G. A., 2008. Comparative study on the performance, emission and combustion studies of a DI diesel engine using distilled tyre pyrolysis oil-diesel blends. Fuel. 87, 2111-21. https://doi.org/10.1016/j.fuel.2008.01.008.

10. Panwar, N. L., Shrirame, H. Y., Rathore, N. S., Jindal, S., Kurchania, A. K., 2010. Performance evaluation of a diesel engine fueled with methyl ester of castor seed oil. Applied Thermal Engineering. 30, 245-9. https://doi.org/10.1016/j.applthermaleng.2009.07.007.

11. Suryawanshi, J. G, Deshpande, N. V., 2005. Effect of injection timing retard on emissions and performance of a pongamia oil methyl ester fuelled $\mathrm{Cl}$ engine. SAE Technical Paper. https://doi.org/10.4271/2005-01-3677.

12. Nwafor, O. M. I., 2000. Effect of advanced injection timing on the performance of natural gas in diesel engines. Sadhana. 25, 11-20. https://doi.org/10.1007/BF02703803.

13. Jaichandar, S., Kumar, P. S., Annamalai, K., 2012. Combined effect of injection timing and combustion chamber geometry on the performance of a biodiesel fueled diesel engine. Energy. 47, 388 - 94. https://doi.org/10.1016/j.energy.2012.09.059.

14. Panneerselvam, N., Murugesan, A., Vijayakumar, C., Kumaravel, A., Subramaniam, D., Avinash, A., 2015. Effects of injection timing on bio-diesel fuelled engine characteristics-An overview. Renewable 
and Sustainable Energy Reviews. 50, 17-31. https://doi.org/10.1016/j.rser.2015.04.157.

15. Senthil, R., Silambarasan, R., Ravichandiran, N., 2015. Influence of injection timing and compression ratio on performance, emission and combustion characteristics of Annona methyl ester operated diesel engine. Alexandria Engineering Journal. 54, 295-302.

https://doi.org/10.1016/j.aej.2015.05.008.

16. Rahman, S. A., Masjuki, H. H., Kalam, M. A., Sanjid, A., Abedin, M. J., 2014. Assessment of emission and performance of compression ignition engine with varying injection timing. Renewable and Sustainable Energy Reviews. 35, 221-30. https://doi.org/10.1016/j.rser.2014.03.049.

17. Mohan, B., Yang, W., Raman, V., Sivasankaralingam, V., Chou, S. K., 2014. Optimization of biodiesel fueled engine to meet emission standards through varying nozzle opening pressure and static injection timing. Applied Energy. 130, 450-7. https://doi.org/10.1016/j.apenergy.2014.02.033.

18. Raheman H., Ghadge S. V., 2008. Performance of diesel engine with biodiesel at varying compression ratio and ignition timing. Fuel. 87, 2659-66. https://doi.org/10.1016/j.fuel.2008.03.006.

19. Laguitton, O., Crua, C., Cowell, T., Heikal, M. R., Gold, M. R., 2007. The effect of compression ratio on exhaust emissions from a PCCl diesel engine. Energy Conversion and Management. 48, $2918-24$. https://doi.org/10.1016/j.enconman.2007.07.016.

20. Rajak, U., Nashine, P., Verma, T. N., 2019. Assessment of diesel engine performance using spirulina microalgae biodiesel. Energy. 166, 1025-36. https://doi.org/10.1016/j.energy.2018.10.098.

21. Sayin, C., Gumus, M., 2011. Impact of compression ratio and injection parameters on the performance and emissions of a DI diesel engine fueled with biodiesel-blended diesel fuel. Applied Thermal Engineering. 31, 3182-8. https://doi.org/10.1016/j.applthermaleng.2011.05.044.

22. Monyem, A., Van, Gerpen, J. H., Canakci, M., 2001. The effect of timing and oxidation on emissions from biodiesel-fueled engines. Transactions of the ASAE. 44, 35.

https://doi.org/10.13031/2013.2301.

23. Ganapathy, T., Gakkhar, R. P., Murugesan, K., 2011. Influence of injection timing on performance, combustion and emission characteristics of Jatropha biodiesel engine. Applied Energy. 88, 4376-86. https://doi.org/10.1016/j.apenergy.2011.05.016.

24. Ozsezen, A. N., Canakci, M., Sayin, C., 2008. Effects of biodiesel from used frying palm oil on the exhaust emissions of an indirect injection (IDI) diesel engine. Energy \& Fuels. 22, 2796 - 804. https://doi.org/10.1021/ef800174p.

25. Liu, T., Jiaqiang, E., Yang, W., Hui, A., Cai, H., 2016. Development of a skeletal mechanism for biodiesel blend surrogates with varying fatty acid methyl esters proportion. Applied Energy. 162,278 - 88. https://doi.org/10.1016/j.apenergy.2015.10.090.

26. Zhang, Z., Jiaqiang, E., Deng, Y., Pham, M., Zuo, W., Peng, Q., Yin, Z., 2018. Effects of fatty acid methyl esters proportion on combustion and emission characteristics of a biodiesel fueled marine diesel engine. Energy Conversion and Management. 159, 244 - 53. https://doi.org/10.1016/j.enconman.2017.12.098. 
27. Jiaqiang, E., Liu, T., Yang, W. M., Li, J., Gong, J., Deng, Y., 2016. Effects of fatty acid methyl esters proportion on combustion and emission characteristics of a biodiesel fueled diesel engine. Energy Conversion and Management. 117, 410-9. https://doi.org/10.1016/j.enconman.2016.03.021.

28. Bari, S., Yu, C. W., Lim, T. H., 2004. Effect of fuel injection timing with waste cooking oil as a fuel in a direct injection diesel engine. Proceedings of the Institution of Mechanical Engineers, Part D: Journal of Automobile Engineering. 218, 93-104. https://doi.org/10.1243/095440704322829209.

29. McCulloch, W. S., Pitts, W. A., 1943. Logical calculus of the ideas immanent in nervous activity. The Bulletin of Mathematical Biophysics. 5, 115 - 33. https://doi.org/10.1007/BF02478259.

30. Verma, T. N., Nashine, P., Singh, D. V., Singh, T. S., Panwar, D., 2017. ANN: Prediction of an experimental heat transfer analysis of concentric tube heat exchanger with corrugated inner tubes. Applied Thermal Engineering. 120, 219 - 27. https://doi.org/10.1016/j.applthermaleng.2017.03.126.

31. Alonso, J. M., Alvarruiz, F., Desantes, J. M., Hernández, L., Hernández, V., Molto, G., 2007. Combining neural networks and genetic algorithms to predict and reduce diesel engine emissions. IEEE transactions on Evolutionary Computation. 11, 46-55. https://ieeexplore.ieee.org/abstract/document/4079607

32. Ghobadian, B., Rahimi, H., Nikbakht, A. M., Najafi, G., Yusaf, T. F., 2009. Diesel engine performance and exhaust emission analysis using waste cooking biodiesel fuel with an artificial neural network. Renewable Energy. 34, 976 - 82. https://doi.org/10.1016/j.renene.2008.08.008.

33. Togun, N. K., Baysec, S., 2010. Prediction of torque and specific fuel consumption of a gasoline engine by using artificial neural networks. Applied Energy. 87, 349 - 55. https://doi.org/10.1016/j.apenergy.2009.08.016.

34. Pai, P. S., Rao, B. S., 2011. Artificial neural network based prediction of performance and emission characteristics of a variable compression ratio $\mathrm{Cl}$ engine using WCO as a biodiesel at different injection timings. Applied Energy. 88, 2344-54. https://doi.org/10.1016/j.apenergy.2010.12.030.

35. Sharon, H., Jayaprakash, R., Sundaresan, A., Karuppasamy, K., 2012. Biodiesel production and prediction of engine performance using SIMULINK model of trained neural network. Fuel. 99, 197203. https://doi.org/10.1016/j.fuel.2012.04.019.

36. Roy, S., Banerjee, R., Bose, P. K., 2014. Performance and exhaust emissions prediction of a CRDI assisted single cylinder diesel engine coupled with EGR using artificial neural network. Applied Energy. 119, 330 - 40. https://doi.org/10.1016/j.apenergy.2014.01.044.

37. Salam, S., Verma, T. N., 2019. Appending empirical modelling to numerical solution for behaviour characterisation of microalgae biodiesel. Energy Conversion and Management 180, 496-510. https://doi.org/10.1016/j.enconman.2018.11.014.

38. Singh, T. S., Verma, T. N., 2019. Taguchi design approach for extraction of methyl ester from waste cooking oil using synthesized $\mathrm{CaO}$ as heterogeneous catalyst: Response surface methodology optimization. Energy Conversion and Management. 182, 383 - 97. https://doi.org/10.1016/j.enconman.2018.12.077. 
39. Singh, T. S., Verma, T. N., 2019. Impact of Tri-Fuel on Compression Ignition Engine Emissions: Blends of Waste Frying Oil-Alcohol-Diesel. InMethanol and the Alternate Fuel Economy. Springer, Singapore. 135-156. https://doi.org/10.1007/978-981-13-3287-6_7.

40. Shrivastava, P., and Verma, T.N., 2020. Effect of fuel injection pressure on the characteristics of $\mathrm{Cl}$ engine fuelled with biodiesel from Roselle oil. Fuel, 265, 117005.

41. Shrivastava, P., Verma, T.N., Samuel, O.D. and Pugazhendhi, A., 2020. An experimental investigation on engine characteristics, cost and energy analysis of $\mathrm{Cl}$ engine fuelled with Roselle, Karanja biodiesel and its blends. Fuel. 275, 117891

42. Rajak, U., Nashine, P., Singh, T. S., Verma, T. N., 2018. Numerical investigation of performance, combustion and emission characteristics of various biofuels. Energy Conversion and Management. 156, 235 - 52. https://doi.org/10.1016/j.enconman.2017.11.017.

43. Sheela, K. G., Deepa, S. N., 2013. Review on methods to fix number of hidden neurons in neural networks. Mathematical Problems in Engineering. http://dx.doi.org/10.1155/2013/425740.

44. Panchal, F. S., Panchal, M., 2014. Review on methods of selecting number of hidden nodes in artificial neural network. International Journal of Computer Science and Mobile Computing. 3, 455 64.

45. Moré, J. J., 1978. The Levenberg-Marquardt algorithm: implementation and theory. In Numerical analysis, Springer, Berlin, Heidelberg. 105-116. https://doi.org/10.1007/BFb0067700.

46. Kumar, S. Neural networks: a classroom approach. Tata McGraw-Hill Education; 2004.

47. Panneerselvam, N., Murugesan, A., Vijayakumar, C., Kumaravel, A., Subramaniam, D., Avinash, A., 2015. Effects of injection timing on bio-diesel fuelled engine characteristics-An overview. Renewable and Sustainable Energy Reviews. 50, 17-31. https://doi.org/10.1016/j.rser.2015.04.157.

48. Ulusoy, Y., Tekin, Y., Cetinkaya, M., Karaosmanoglu, F., 2004. The engine tests of biodiesel from used frying oil. Energy Sources. 26, 927 - 32. https://doi.org/10.1080/00908310490473219.

49. Singh, T. S., Verma, T. N., Nashine, P., Shijagurumayum, C., 2018. BS-III Diesel Vehicles in Imphal, India: an emission perspective. InAir Pollution and Control. Springer, Singapore. 73-86. https://doi.org/10.1007/978-981-10-7185-0_5.

50. Huang, Z., Lu, H., Jiang, D., Zeng, K., Liu, B., Zhang, J., Wang, X., 2005. Performance and emissions of a compression ignition engine fueled with diesel/oxygenate blends for various fuel delivery advance angles. Energy and Fuels. 19, 403 - 10. https://pubs.acs.org/doi/abs/10.1021/ef049855d.

51. Salam, S., Verma, T. N., 2019. Appending empirical modelling to numerical solution for behaviour characterisation of microalgae biodiesel. Energy Conversion and Management. 180, 496-510. https://doi.org/10.1016/j.enconman.2018.11.014.

52. Shrivastava, P., Verma, T. N., Pugazhendhi, A., 2019. An experimental evaluation of engine performance and emisssion characteristics of $\mathrm{Cl}$ engine operated with Roselle and Karanja biodiesel. Fuel. 254, 115652.

53. Shrivastava, P., Verma, T. N., 2019 An experimental investigation into engine characteristics fueled with Lal ambari biodiesel and its blends. Thermal Science and Engineering Progress. 100356. 
54. Singh, T. S., Verma, T. N., 2019. An assessment study of using Turel Kongreng (river mussels) as a source of heterogeneous catalyst for biofuel production. Biocatalysis and Agricultural Biotechnology. 20, 101185.

55. Shrivastava, P., Verma, T. N., Samuel, O. D., 2019 Experimental and empirical analysis of an IC engine operating with ternary blends of diesel, karanja and roselle biodiesel. Fuel. 116608.

\section{Tables}

Due to technical limitations, table 1 to 7 is only available as a download in the Supplemental Files section.

\section{Figures}

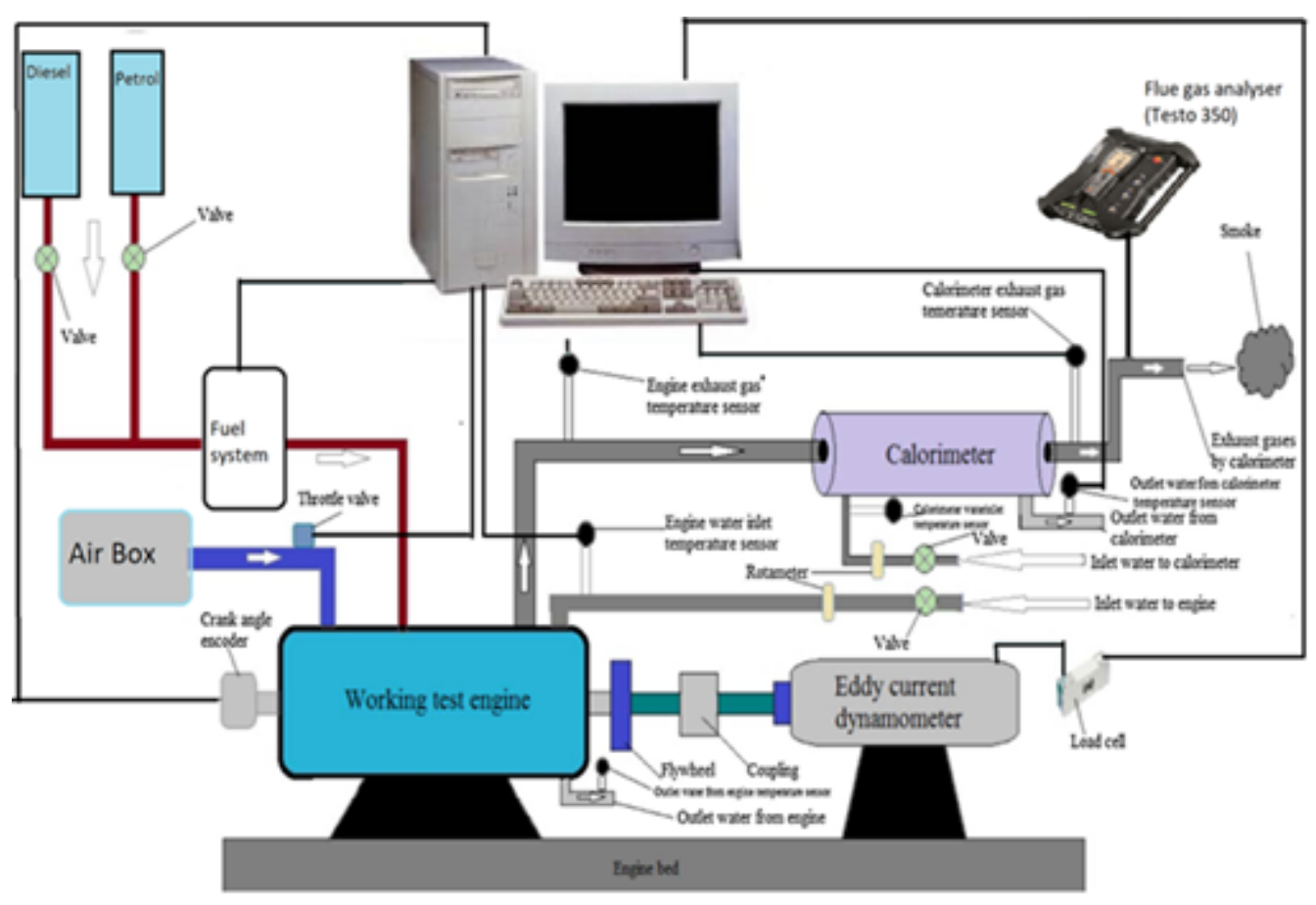

Figure 1

Experiemtal setup. 

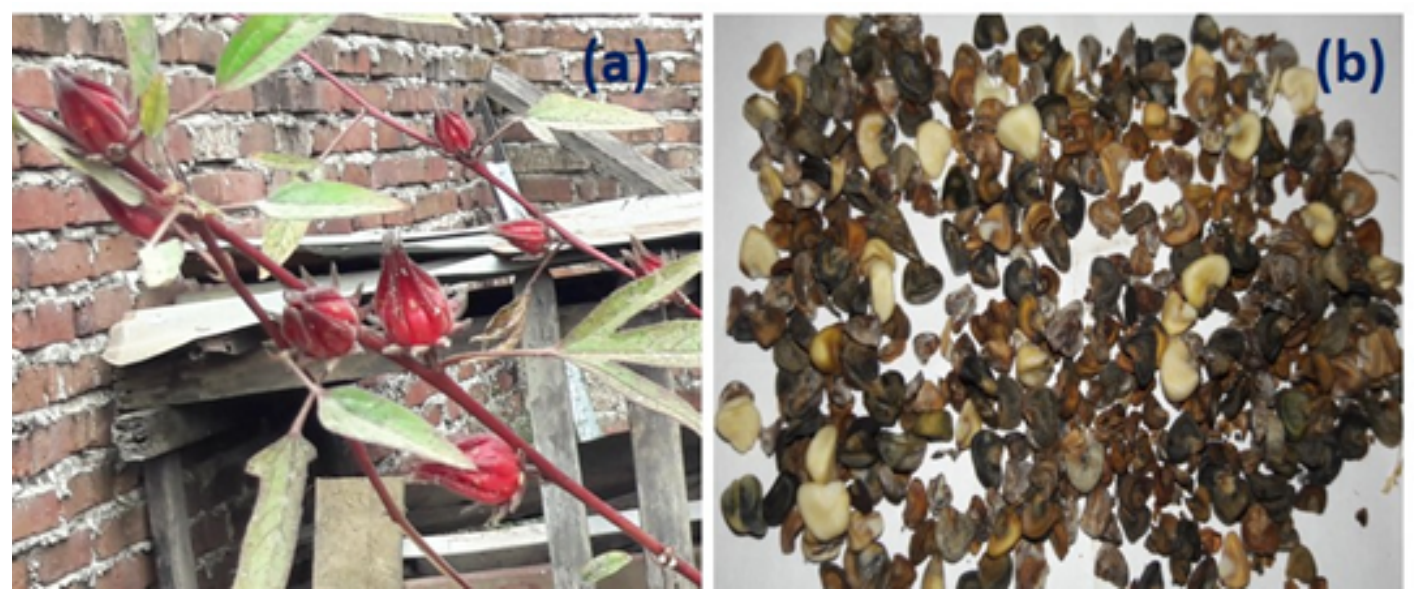

Figure 2

Roselle plant and seeds.

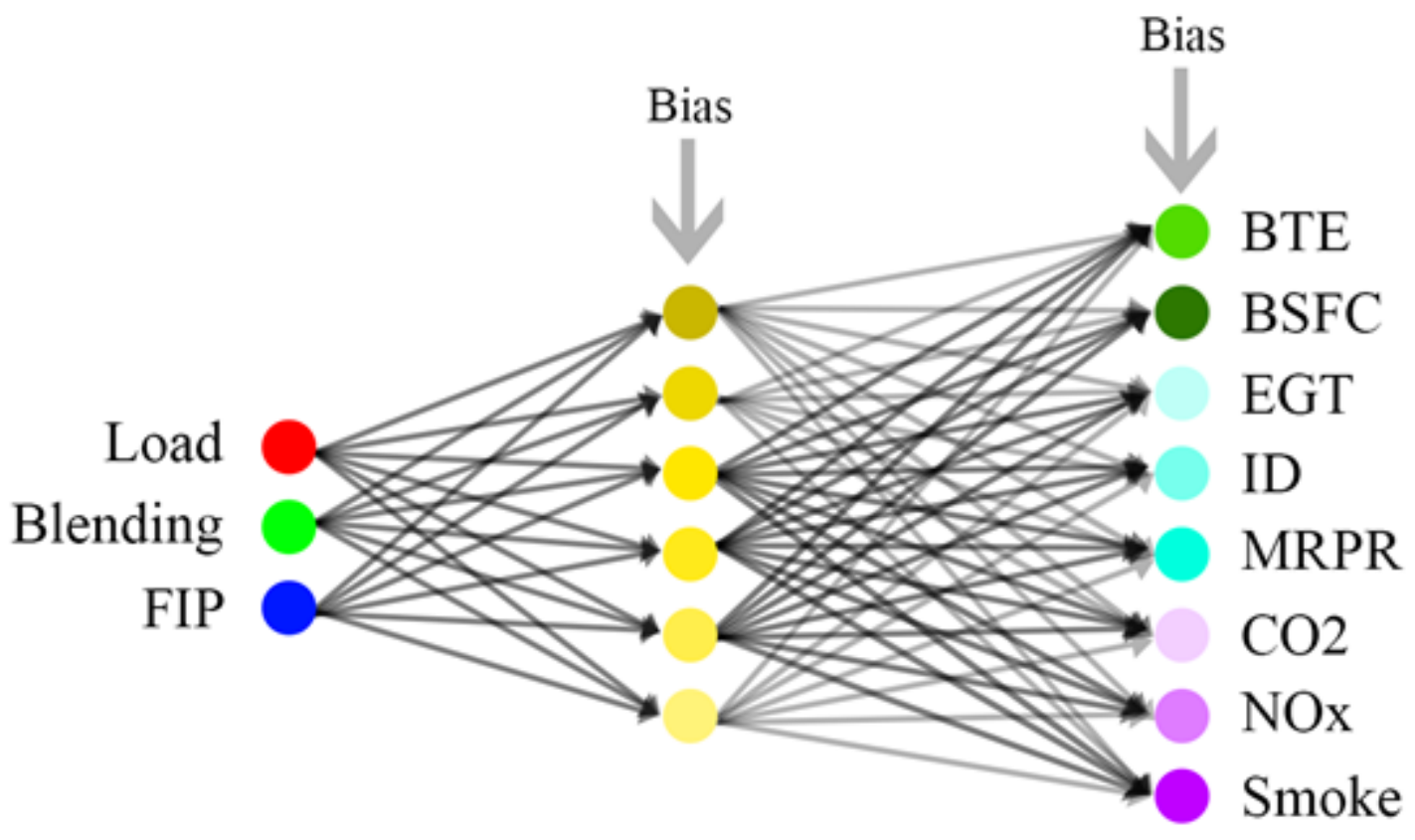

Figure 3

Schematic of ANN. 


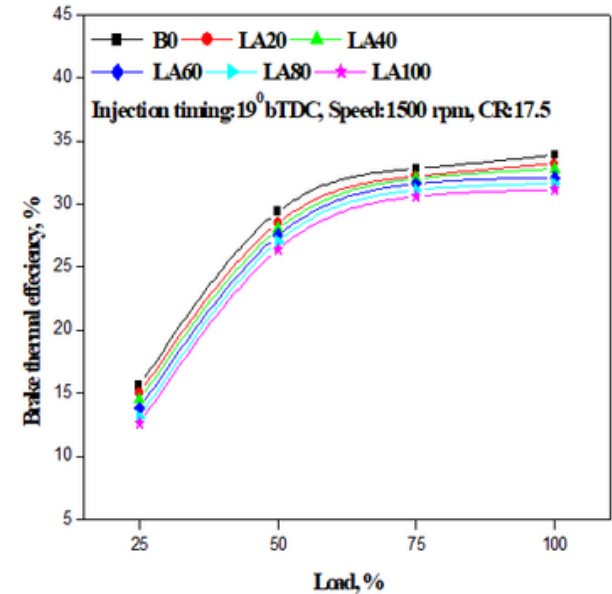

(a) Injection timing $19^{\circ} \mathrm{bTDC}$

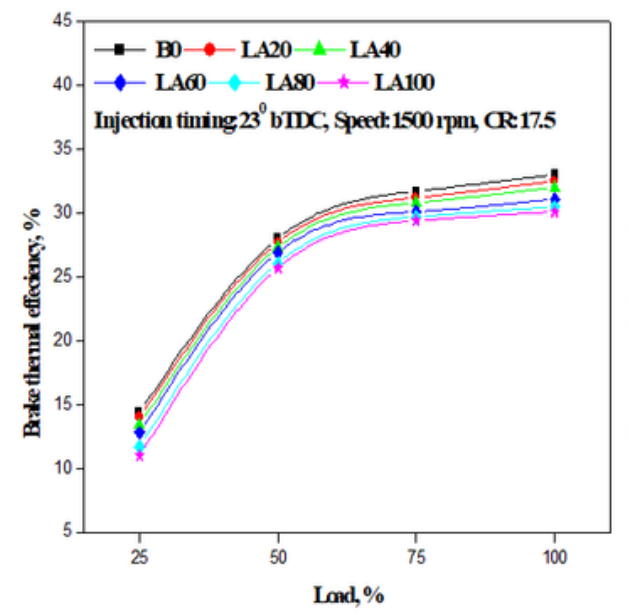

(c) Injection timing $23^{\circ} \mathrm{bTDC}$

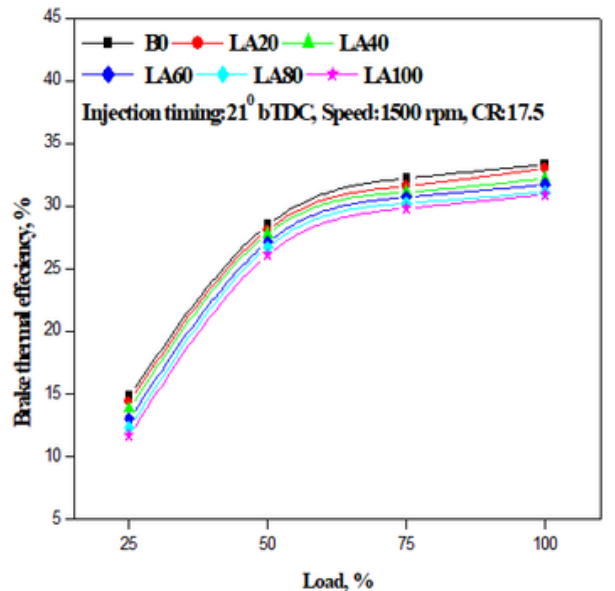

(b) Injection timing $21^{\circ} \mathrm{bTDC}$

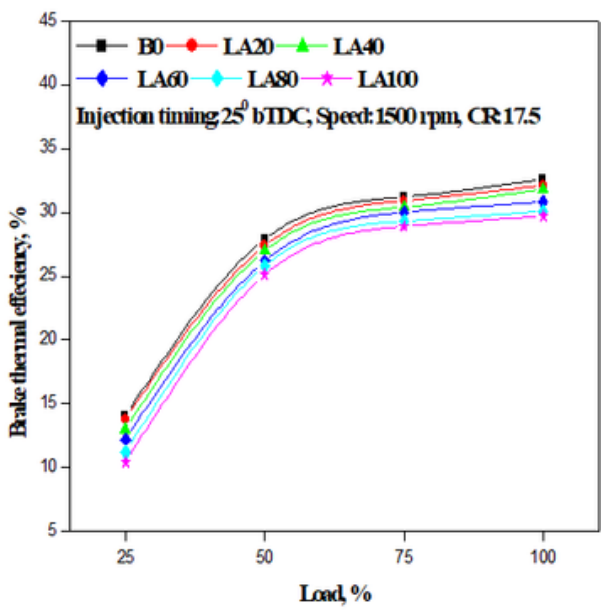

(d) Injection timing $25^{\circ} \mathrm{bTDC}$

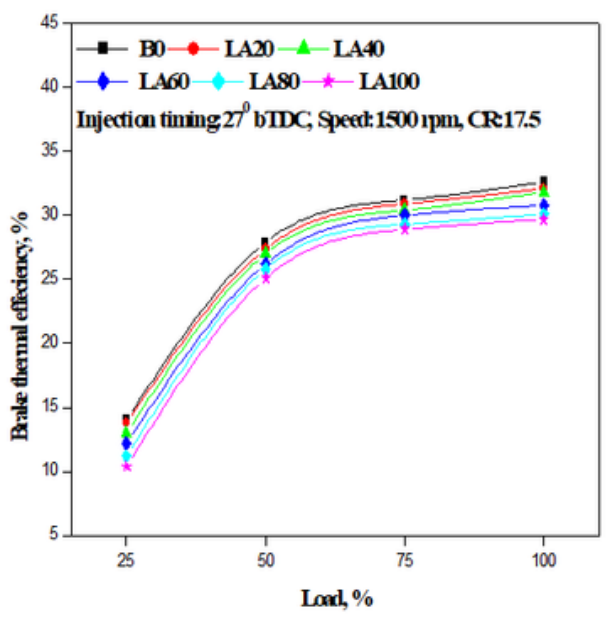

(e) Injection timing $27^{\circ} \mathrm{bTDC}$

\section{Figure 4}

(a-e). The variation in BTE with different injection timing and engine load for various tested fuel. 


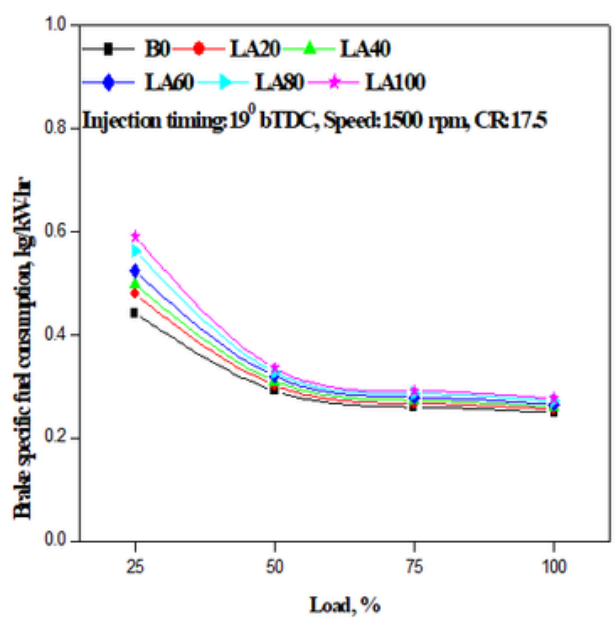

(a) Injection timing $19^{\circ} \mathrm{bTDC}$

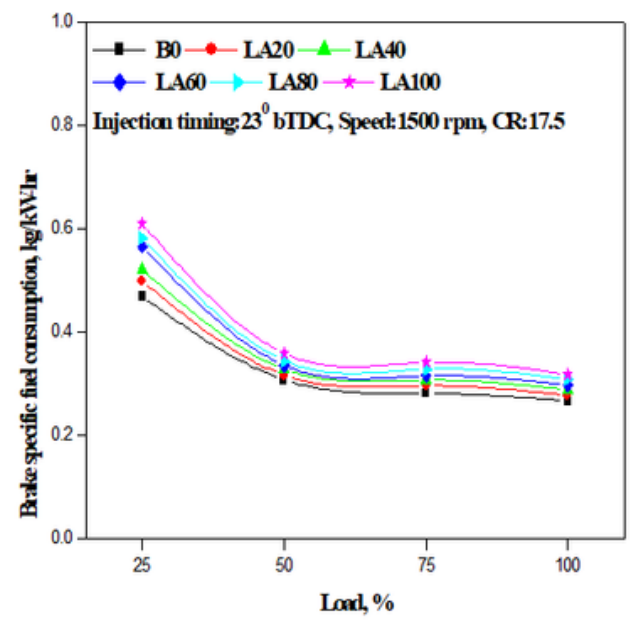

(c) Injection timing $23^{\circ} \mathrm{bTDC}$

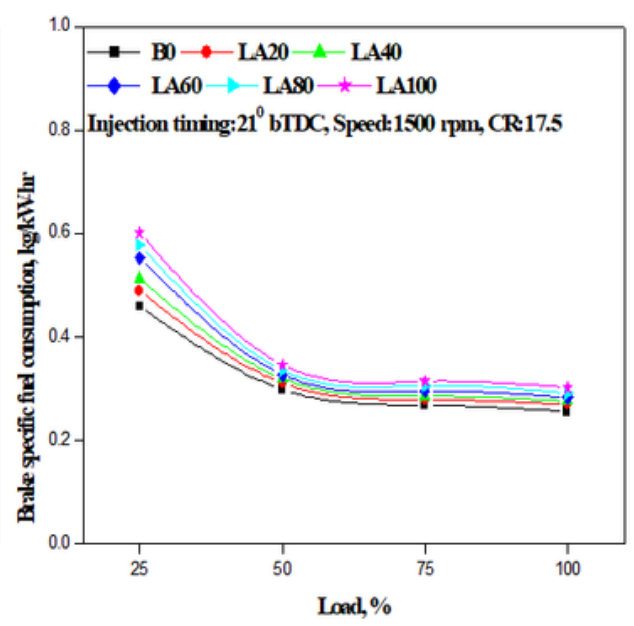

(b) Injection timing $21^{\circ} \mathrm{bTDC}$

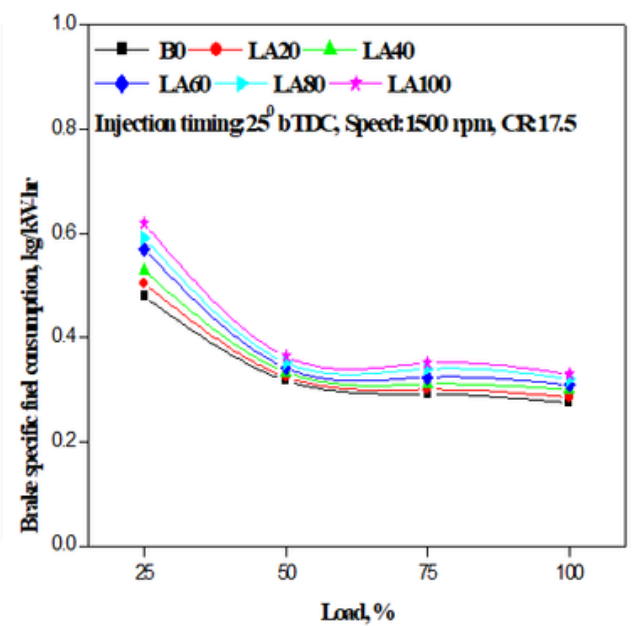

(d) Injection timing $25^{\circ} \mathrm{bTDC}$

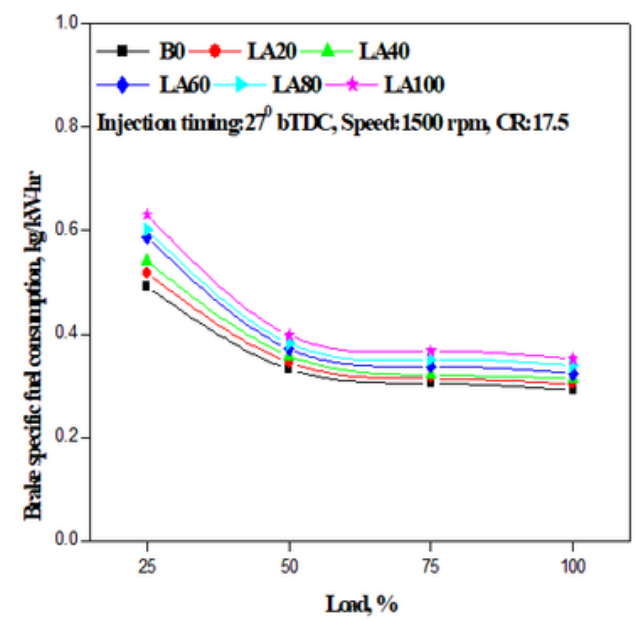

(e) Injection timing $27^{\circ} \mathrm{bTDC}$

\section{Figure 5}

(a-e). The variation in BSFC with different injection timing and engine load for various tested fuel. 

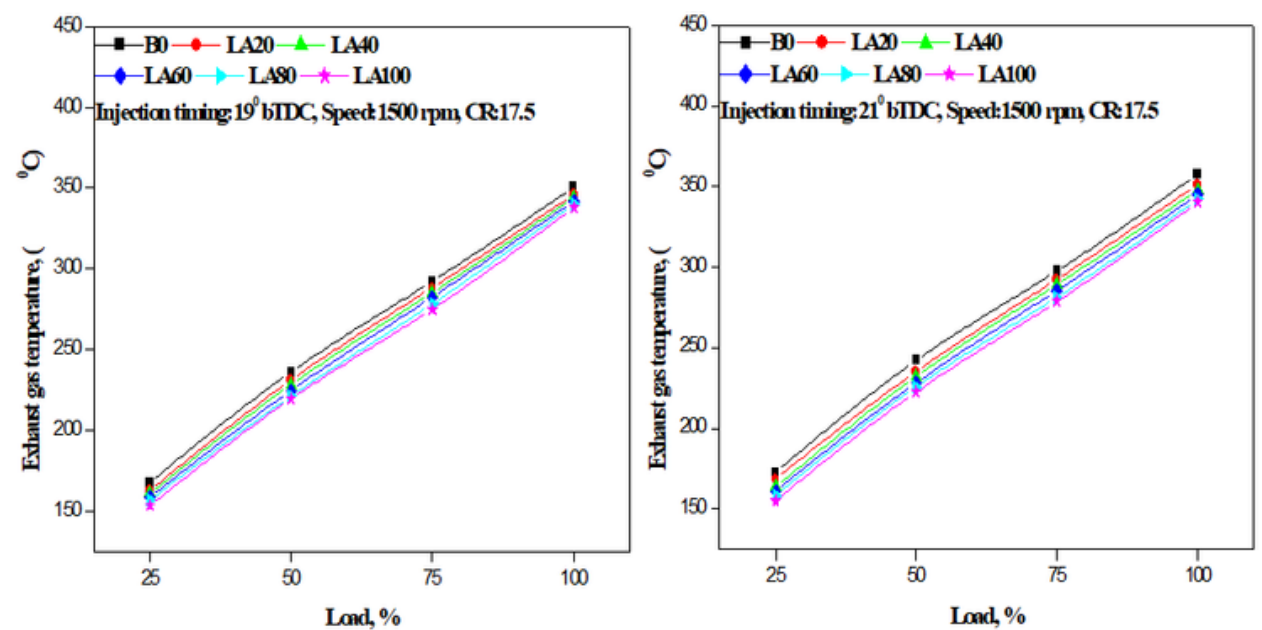

(a) Injection timing $19^{\circ} \mathrm{bTDC}$

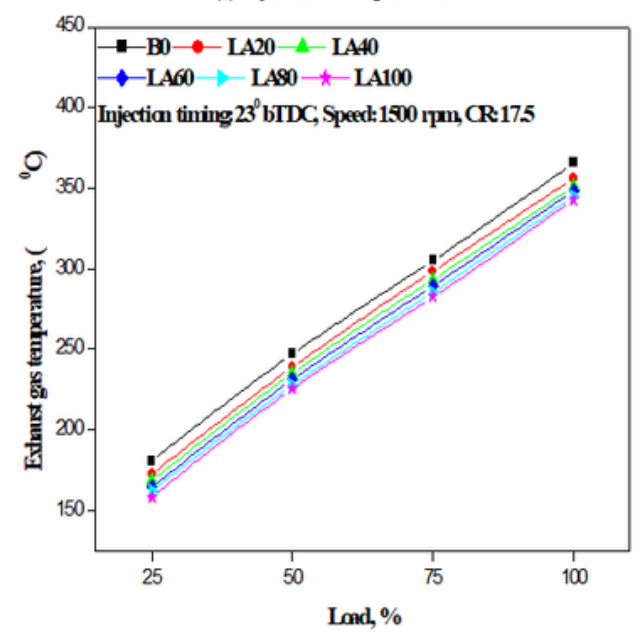

(b) Injection timing $21^{\circ} \mathrm{bTDC}$

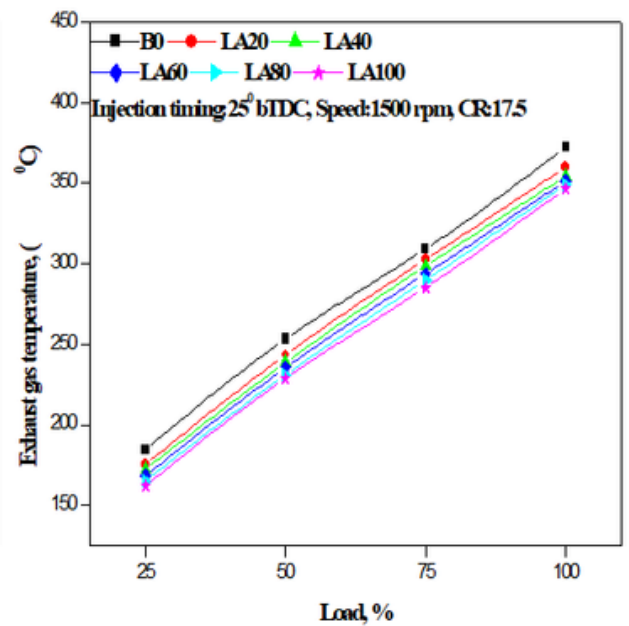

(c) Injection timing $23^{\circ} \mathrm{bTDC}$

(d) Injection timing $25^{\circ} \mathrm{bTDC}$

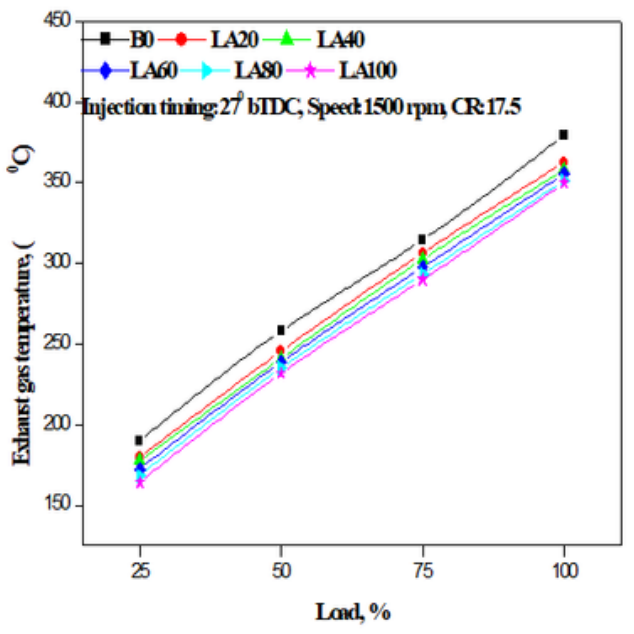

(e) Injection timing $27^{\circ} \mathrm{bTDC}$

\section{Figure 6}

(a-e). The variation in EGT with different injection timing and engine load for various tested fuel 


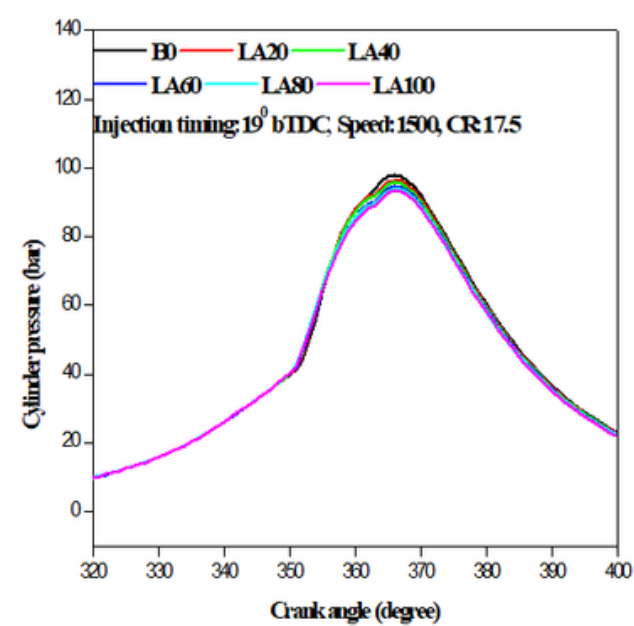

(a) Injection timing $19^{\circ} \mathrm{bTDC}$

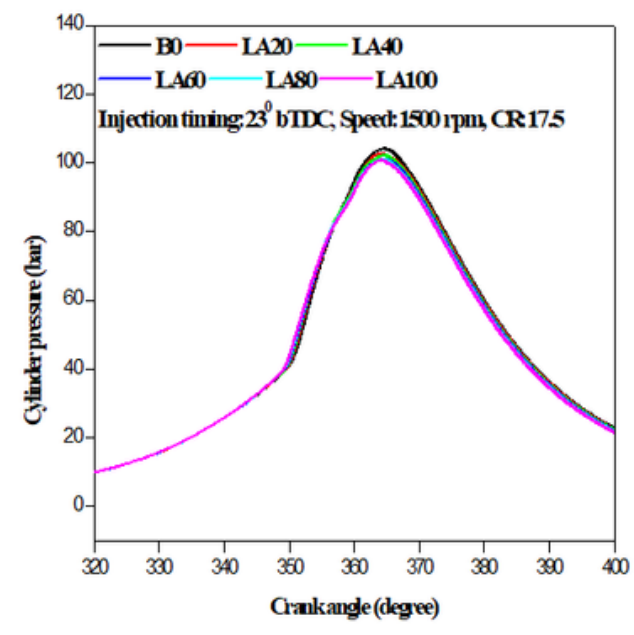

(c) Injection timing $23^{\circ} \mathrm{bTDC}$

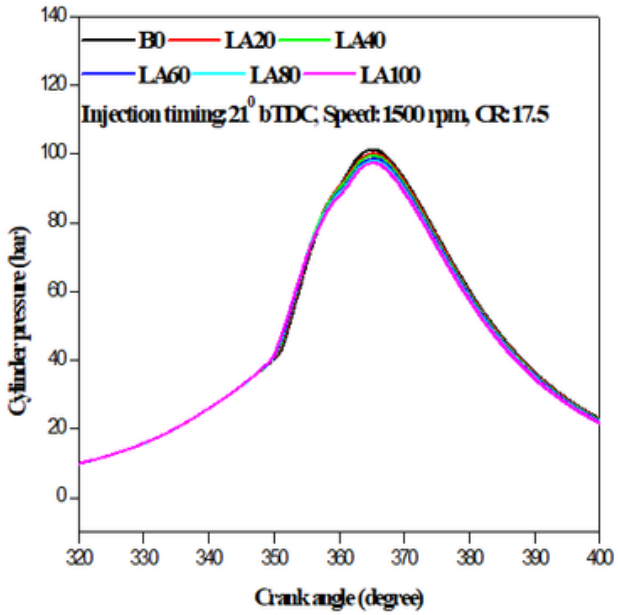

(b) Injection timing $21^{\circ} \mathrm{bTDC}$

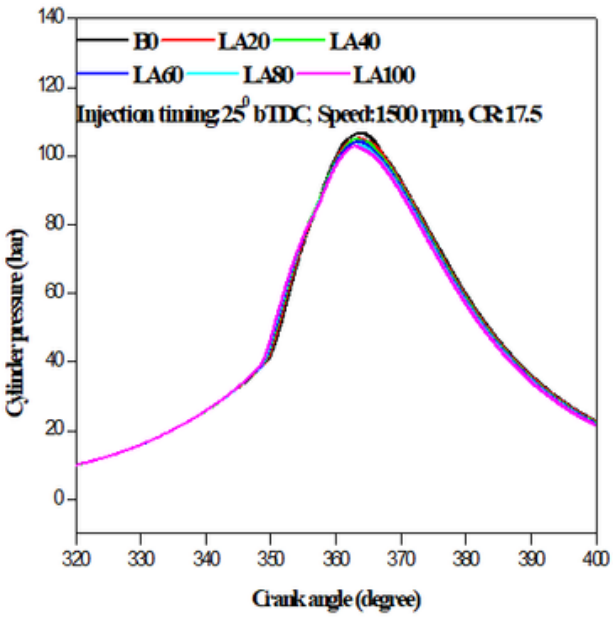

(d) Injection timing $25^{\circ} \mathrm{bTDC}$

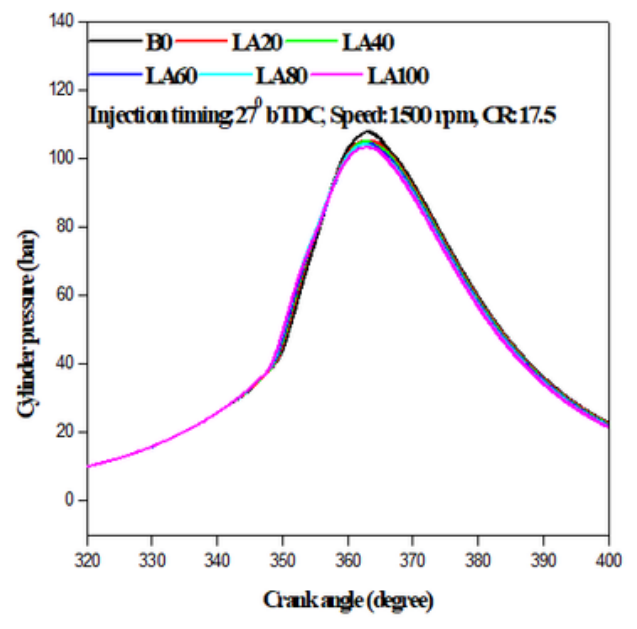

(e) Injection timing $27^{\circ} \mathrm{bTDC}$

\section{Figure 7}

(a-e). The variation in cylinder pressure with different injection timing and engine load for various tested fuel. 


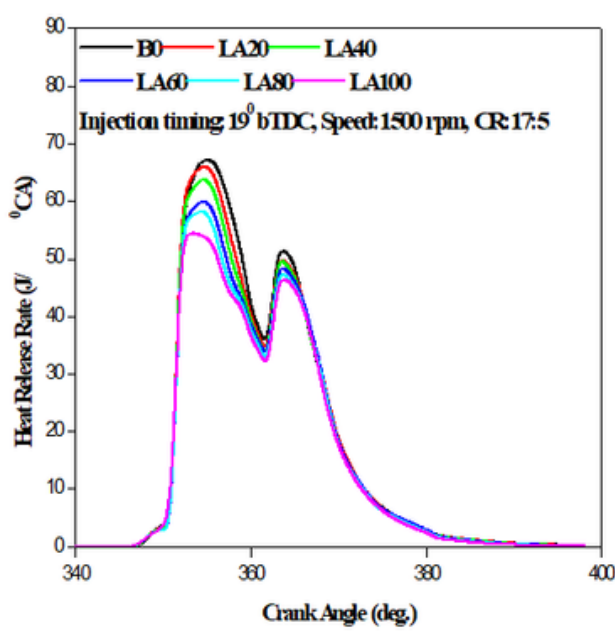

(a) Injection timing $19^{\circ} \mathrm{bTDC}$

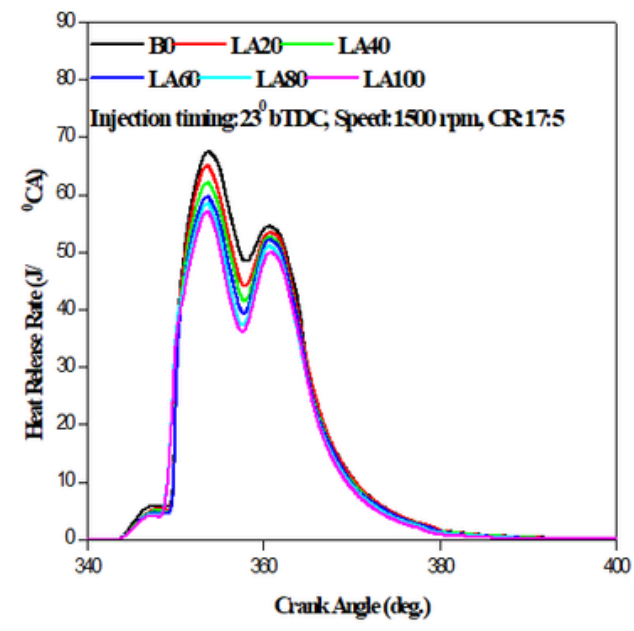

(c) Injection timing $23^{\circ} \mathrm{bTDC}$

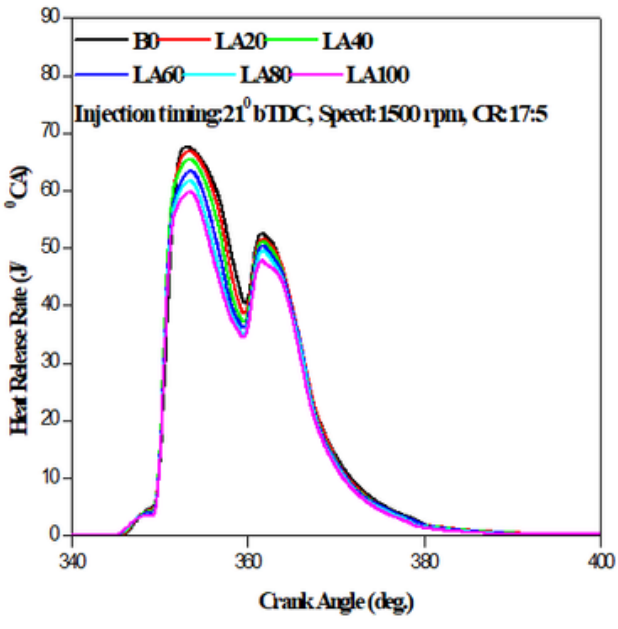

(b) Injection timing $21^{\circ} \mathrm{bTDC}$

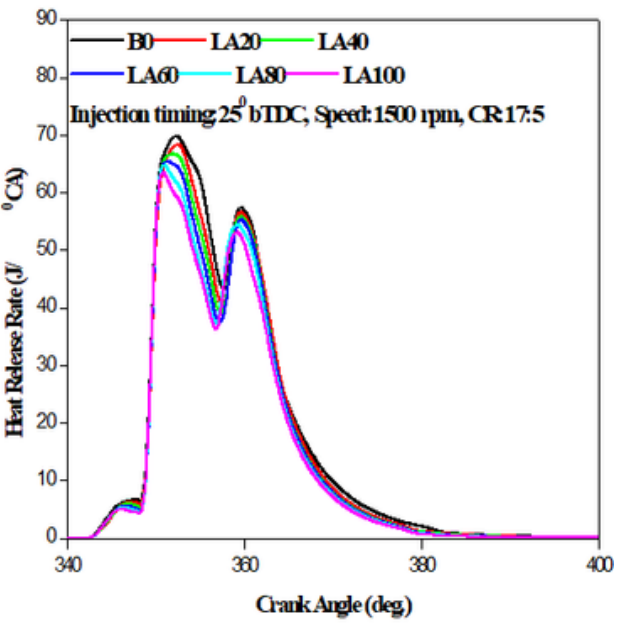

(d) Injection timing $25^{\circ} \mathrm{bTDC}$

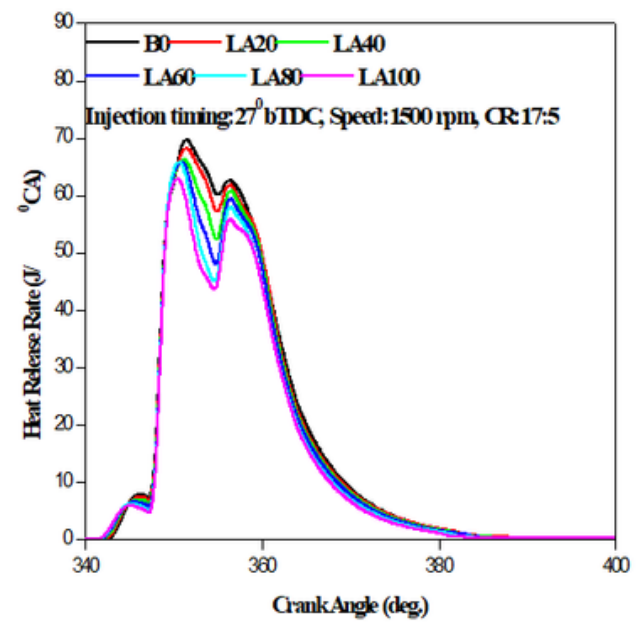

(e) Injection timing $27^{\circ} \mathrm{bTDC}$

\section{Figure 8}

(a-e). The variation in HRR with different injection timing and engine load for various tested fuel. 


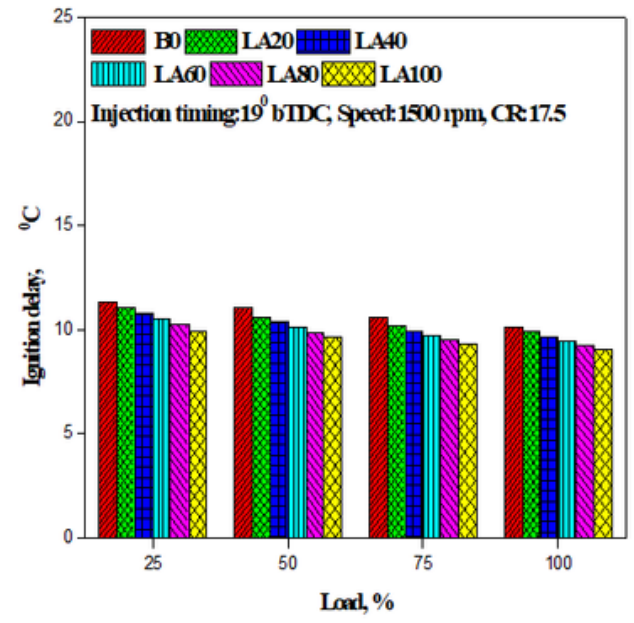

(a) Injection timing $19^{\circ} \mathrm{bTDC}$

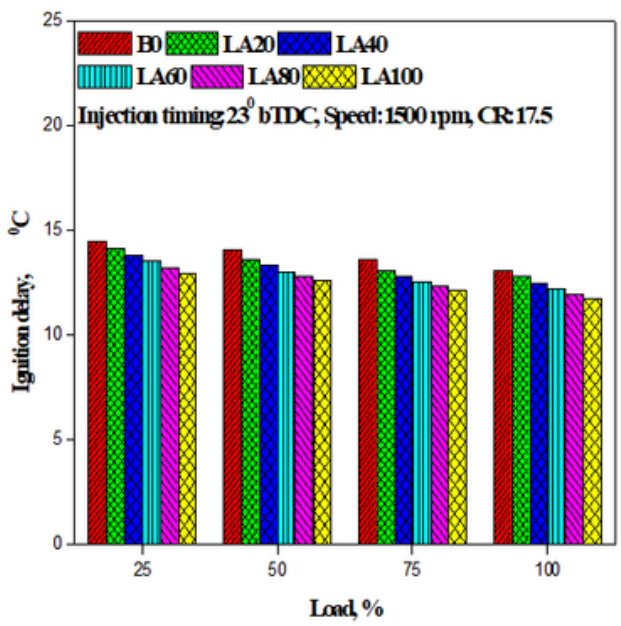

(c) Injection timing $23^{\circ} \mathrm{bTDC}$



(b) Injection timing $21^{\circ} \mathrm{bTDC}$

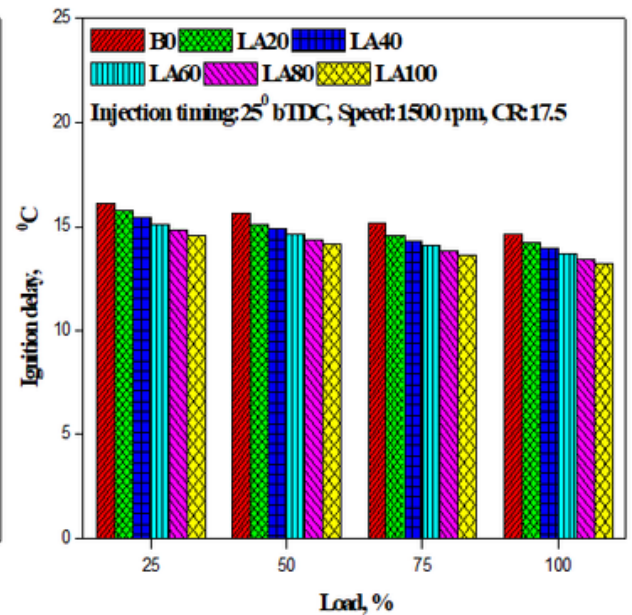

(d) Injection timing $25^{\circ} \mathrm{bTDC}$

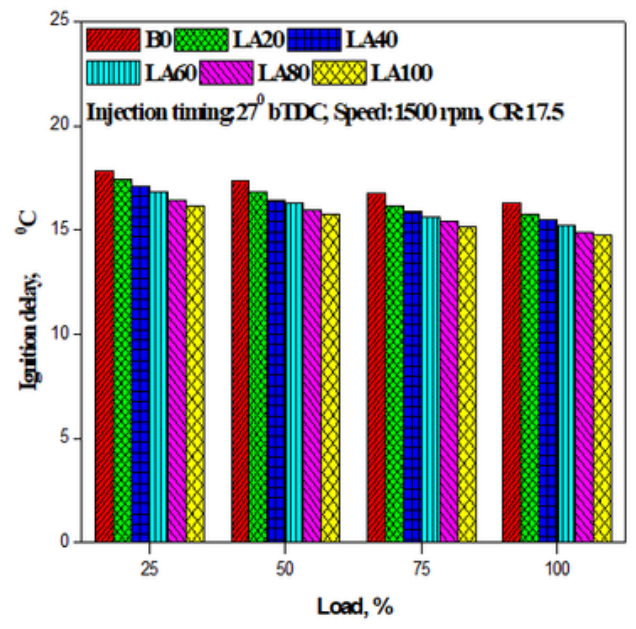

(e) Injection timing $27^{\circ} \mathrm{bTDC}$

\section{Figure 9}

(a-e). The variation in ID with different injection timing and engine load for various tested fuel. 


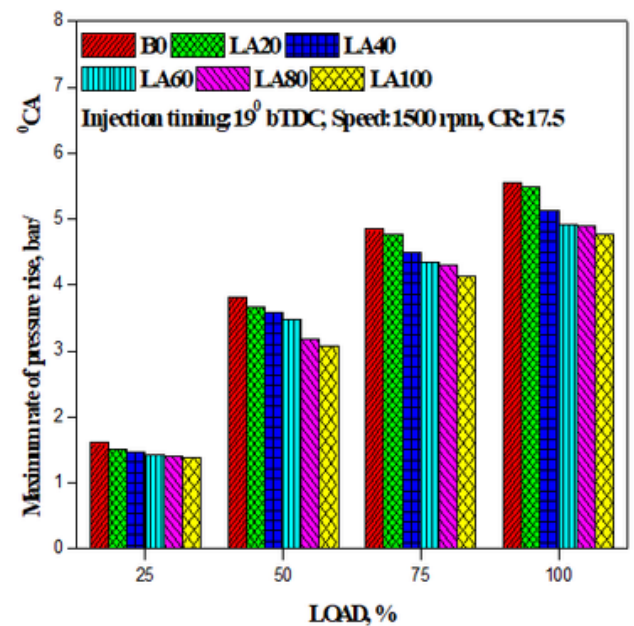

(a) Injection timing $19^{\circ} \mathrm{bTDC}$

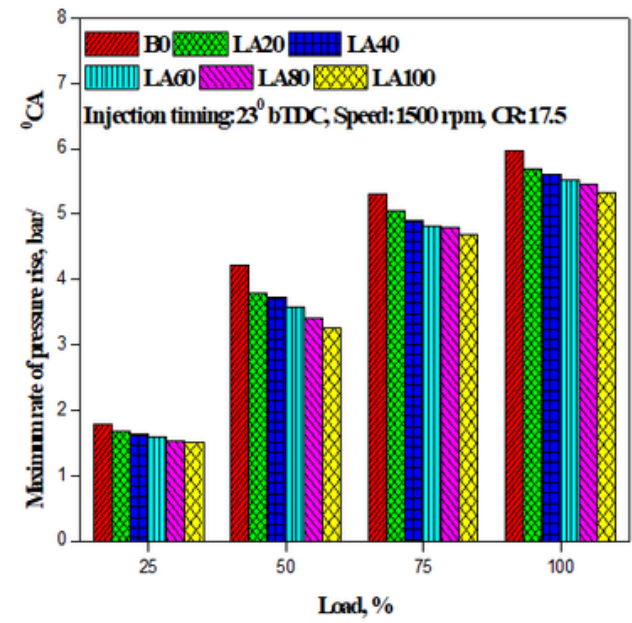

(c) Injection timing $23^{\circ} \mathrm{bTDC}$

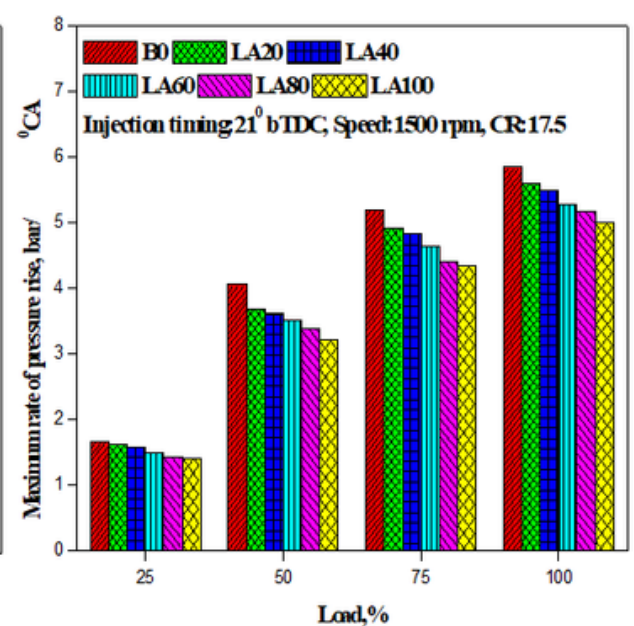

(b) Injection timing $21^{\circ} \mathrm{bTDC}$

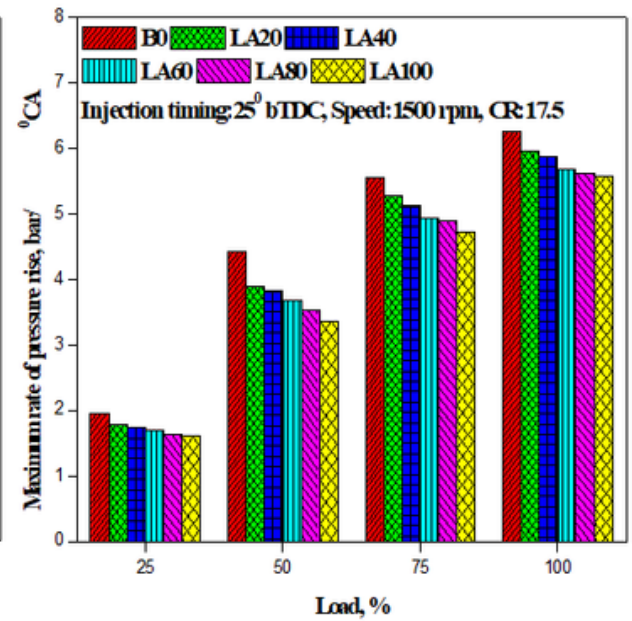

(d) Injection timing $25^{\circ} \mathrm{bTDC}$



(e) Injection timing $27^{\circ} \mathrm{bTDC}$

Figure 10

(a-e). The variation in MRPR with different injection timing and engine load for various tested fuel. 


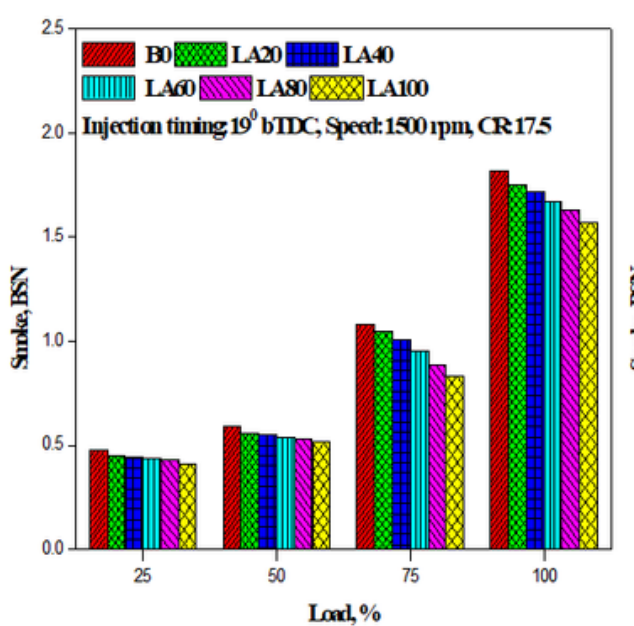

(a) Injection timing $19^{\circ} \mathrm{bTDC}$

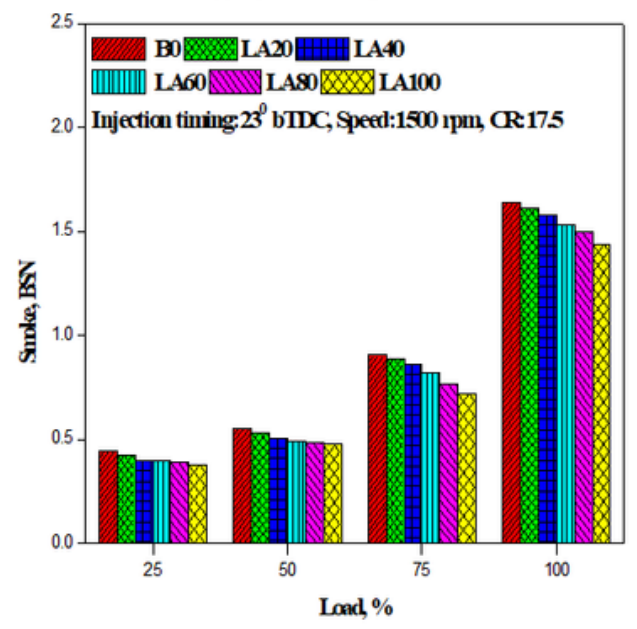

(c) Injection timing $23^{\circ} \mathrm{bTDC}$

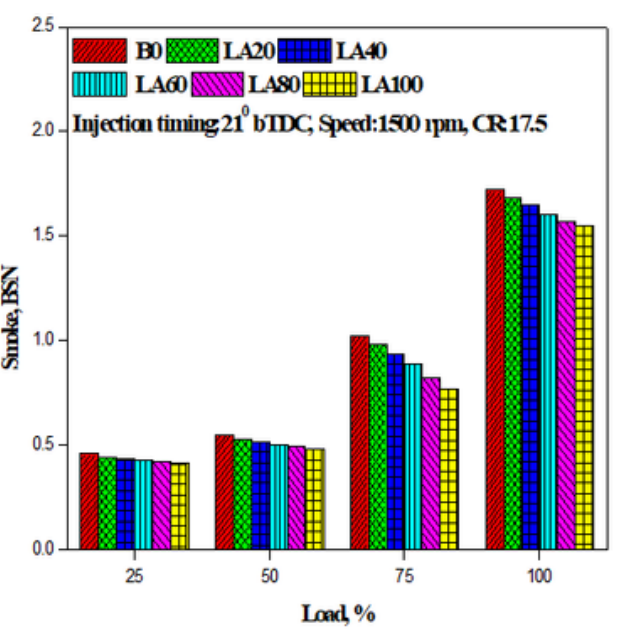

(b) Injection timing $21^{\circ} \mathrm{bTDC}$

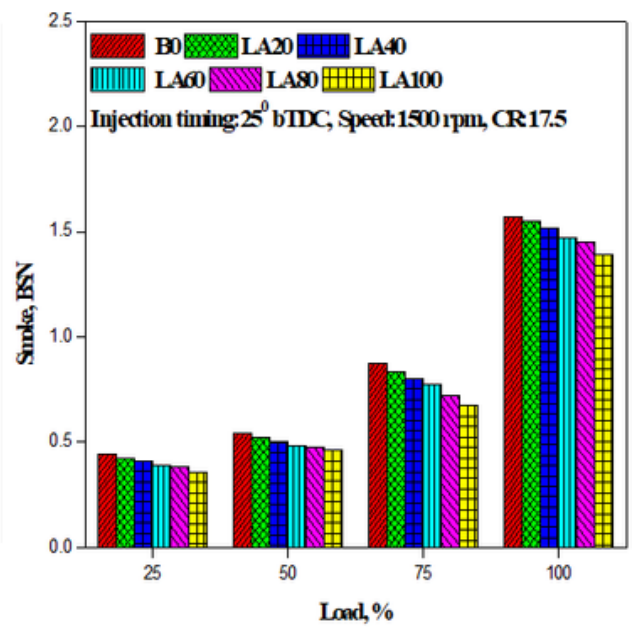

(d) Injection timing $25^{\circ} \mathrm{bTDC}$

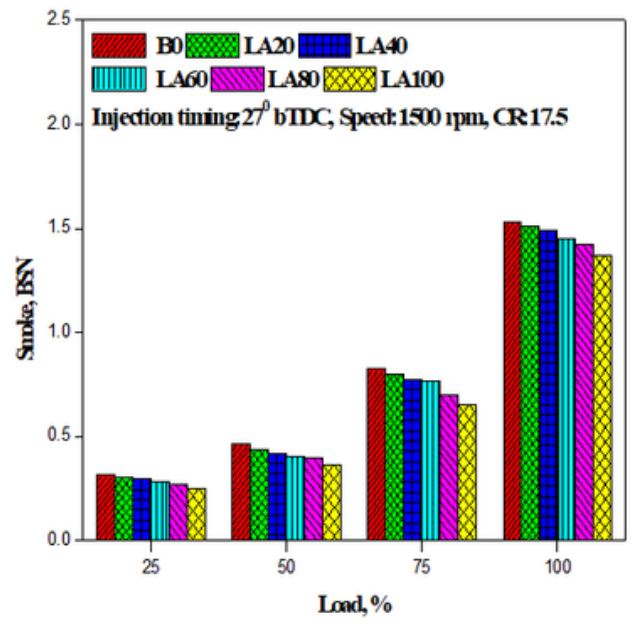

(e) Injection timing $27^{\circ} \mathrm{bTDC}$

\section{Figure 11}

(a-e). The variation in smoke emision with different injection timing and engine load for various tested fuel. 


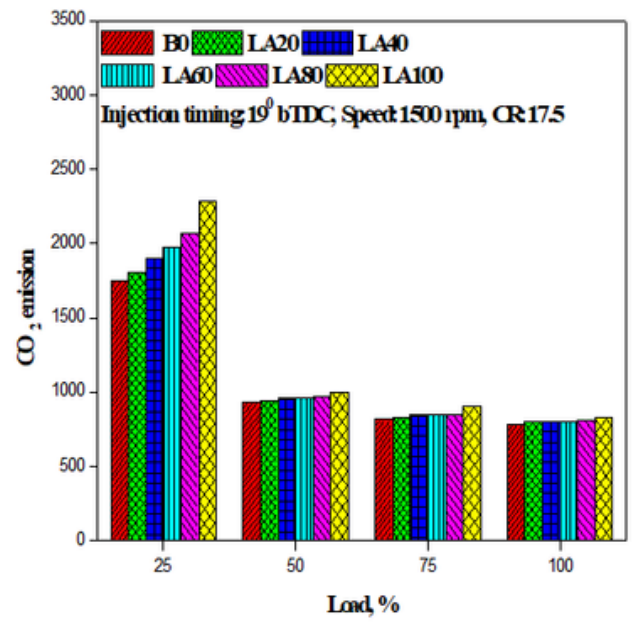

(a) Injection timing $19^{\circ} \mathrm{bTDC}$

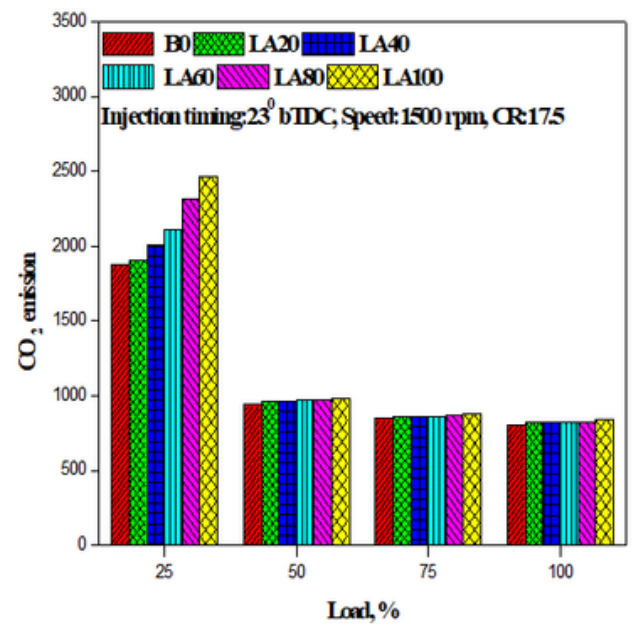

(c) Injection timing $23^{\circ} \mathrm{bTDC}$

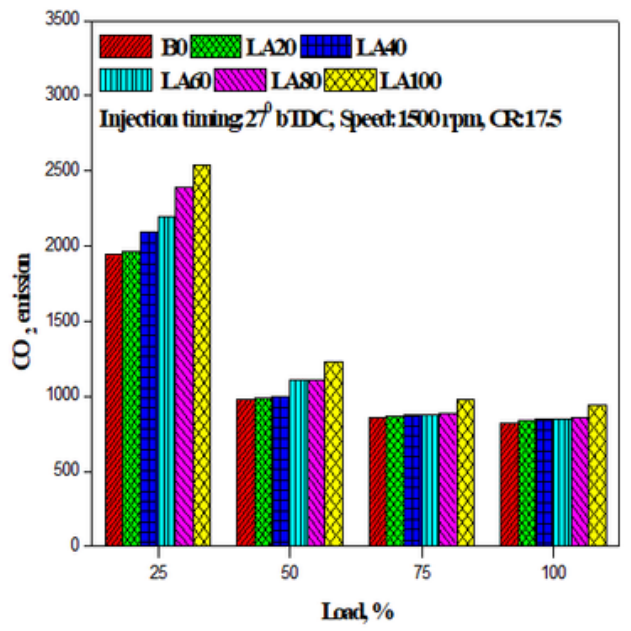

(e) Injection timing $27^{\circ} \mathrm{bTDC}$

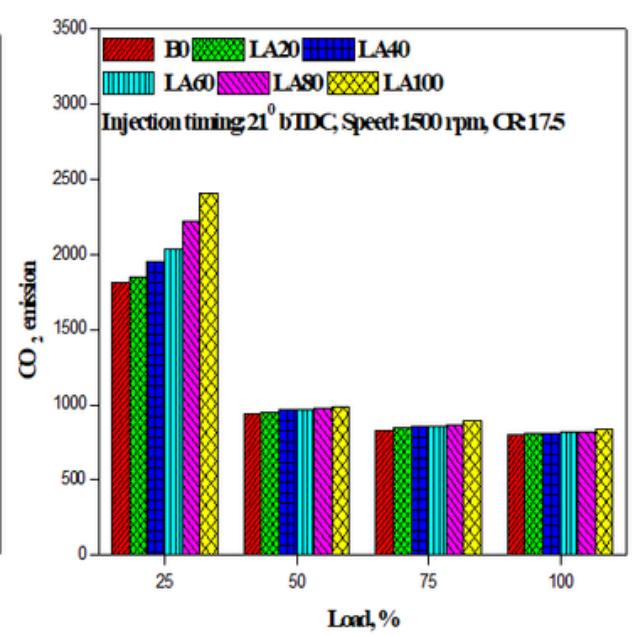

(b) Injection timing $21^{\circ} \mathrm{bTDC}$

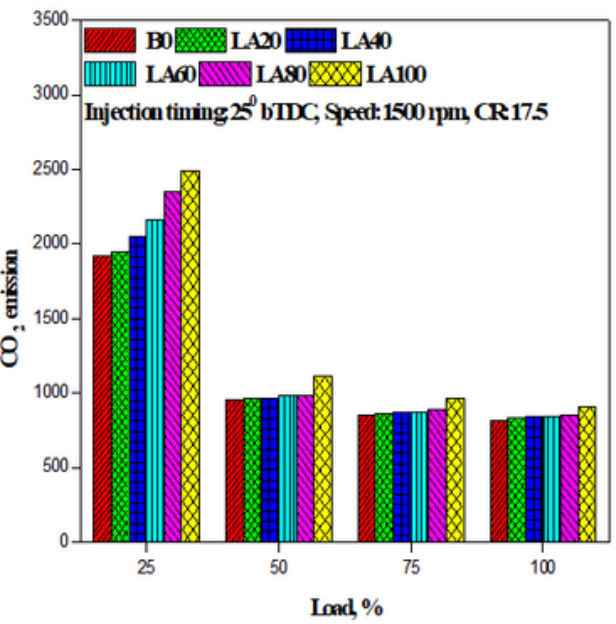

(d) Injection timing $25^{\circ} \mathrm{bTDC}$

\section{Figure 12}

(a-e). The variation in $\mathrm{CO} 2$ emision with different injection timing and engine load for various tested fuel. 


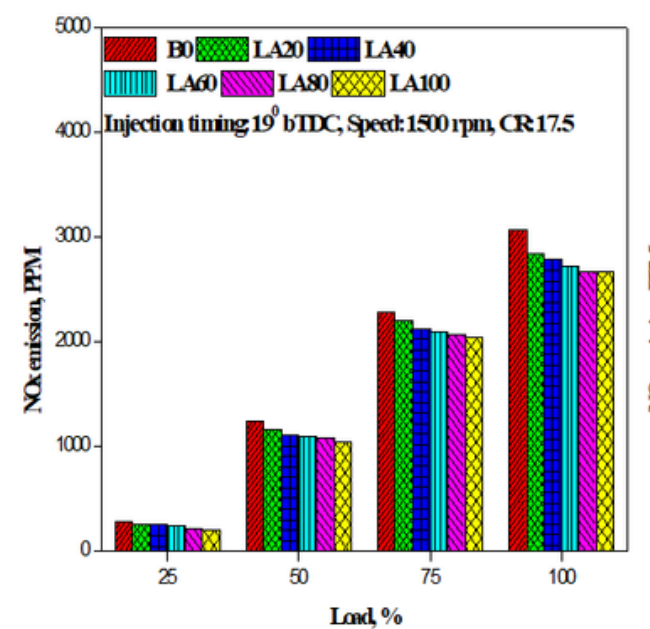

(a) Injection timing $19^{\circ} \mathrm{bTDC}$

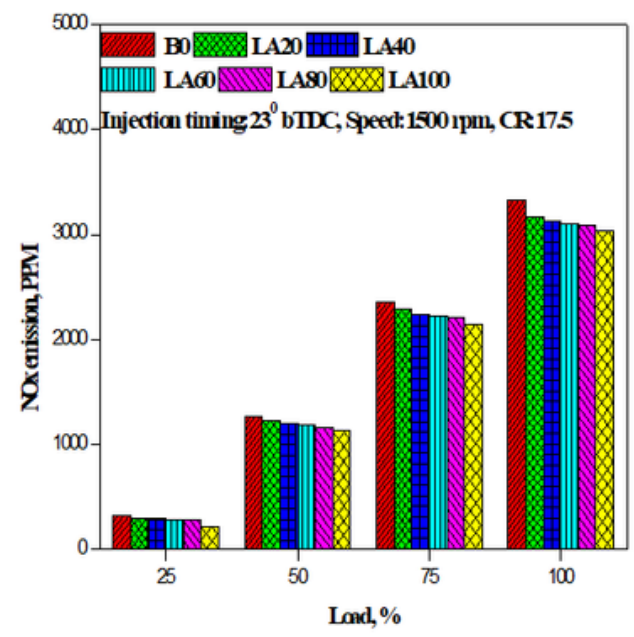

(c) Injection timing $23^{\circ} \mathrm{bTDC}$

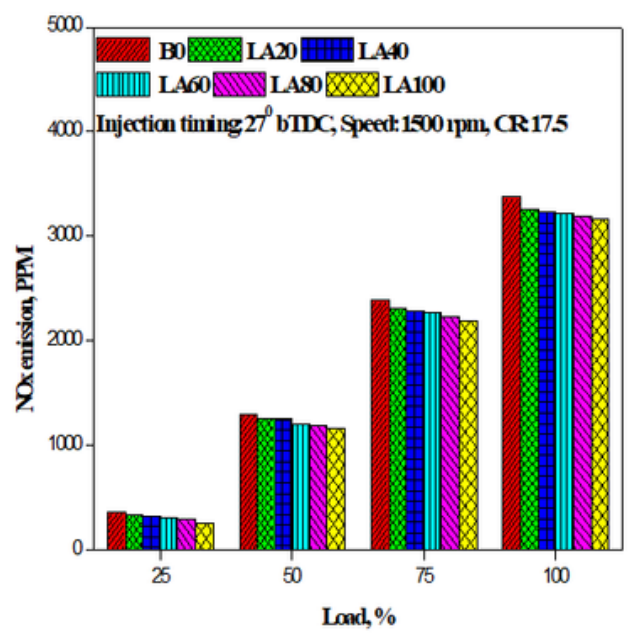

(e) Injection timing $27^{\circ} \mathrm{bTDC}$

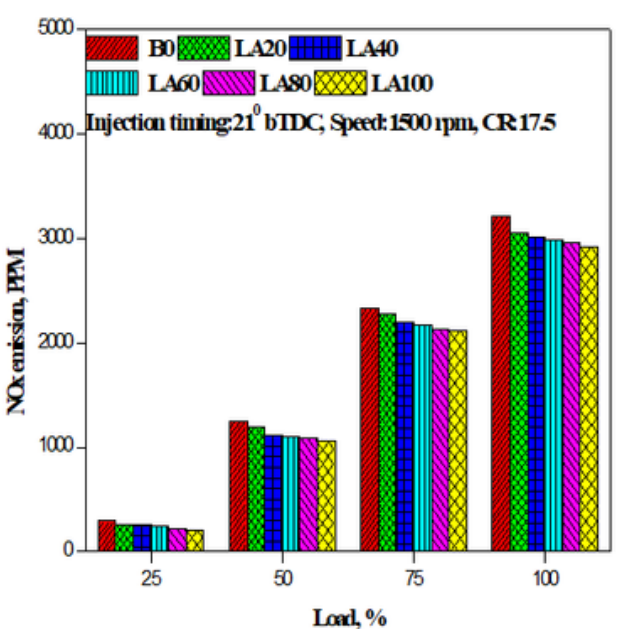

(b) Injection timing $21^{\circ} \mathrm{bTDC}$

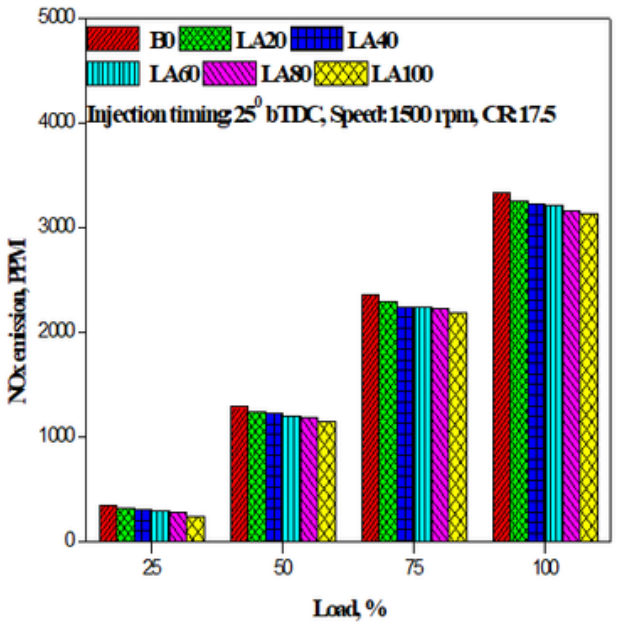

(d) Injection timing $25^{\circ} \mathrm{bTDC}$

\section{Figure 13}

(a-e). The variation in NOX emision with different injection timing and engine load for various tested fuel. 

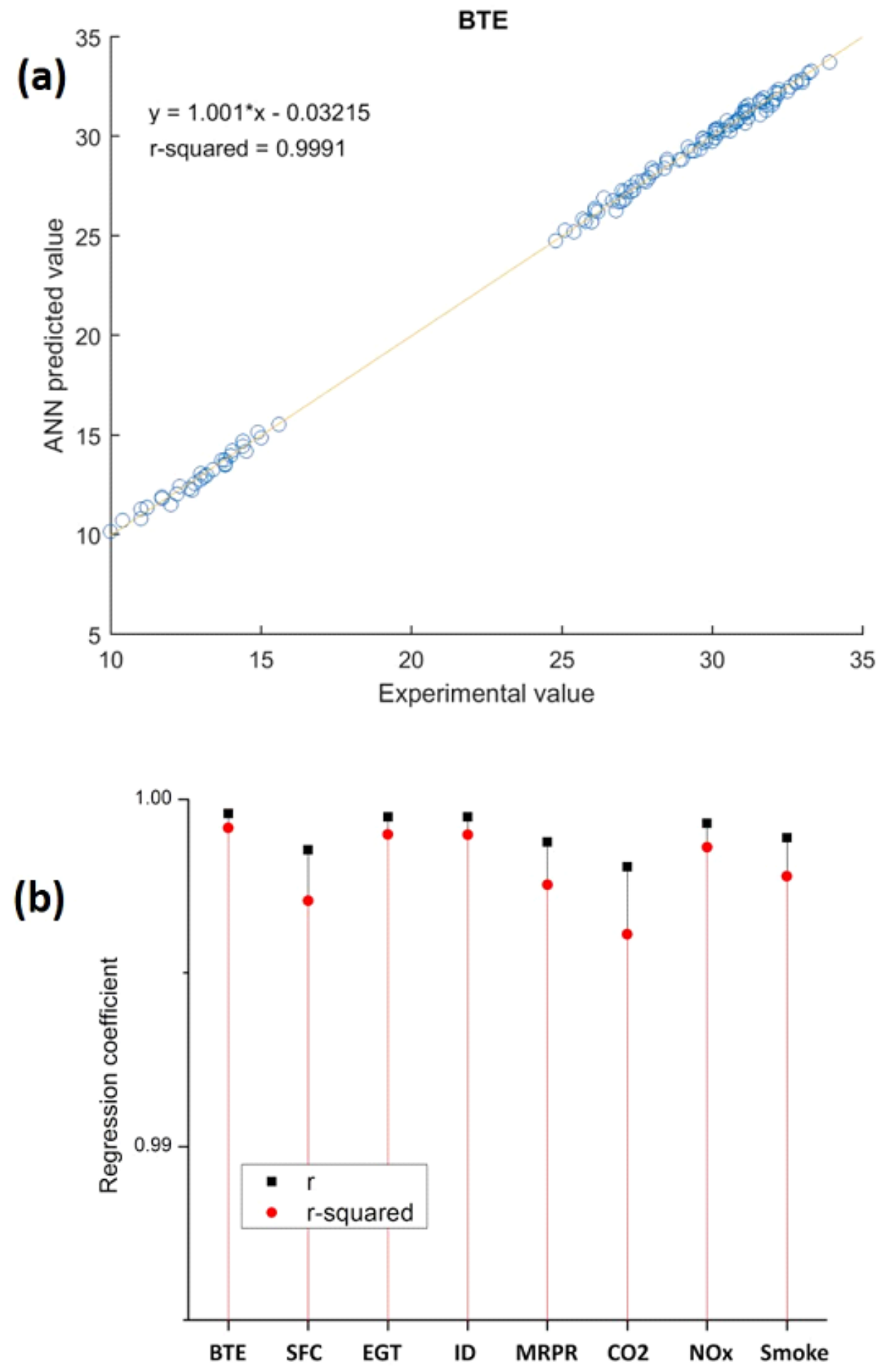

Figure 14

$(a-b)$. The the prediction accuracy for all the responses. 


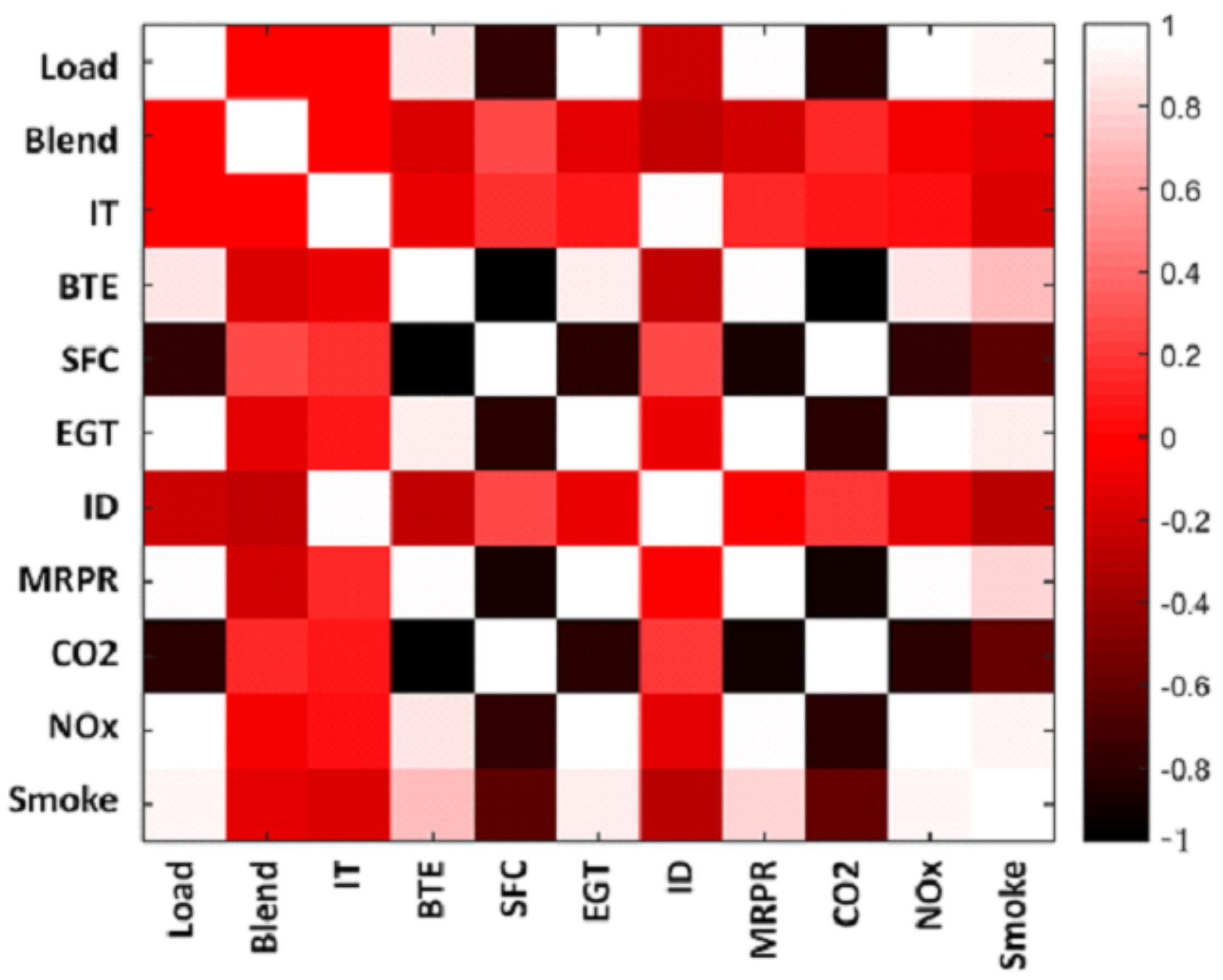

Figure 15

Despite the non-linearity in the reported responses.

\section{Supplementary Files}

This is a list of supplementary files associated with this preprint. Click to download.

- Tables.docx 